\title{
EL CONTROL DE CONSTITUCIONALIDAD DE LAS OMISIONES LEGISLATIVAS. ALGUNAS CUESTIONES DOGMÁTICAS
}

\author{
Control of the constitutionality of legislative omissions. \\ Some dogmatic questiones
}

\author{
Francisco Fernández Segado* \\ Catedrático de Derecho Constitucional \\ Universidad Complutense de Madrid \\ fdezsegado@der.ucm.es
}

\begin{abstract}
RESUMEN: El autor analiza el tema siempre actual en el derecho constitucional comparado sobre la institución del control de constitucionalidad de las omisiones legislativas, pasando revista a su surgimiento y desarrollo histórico, su clasificación y taxonomía, la doctrina desarrollada sobre la institución y su concreción en las constituciones a través del tiempo, como asimismo la situación actual de la institución en el derecho constitucional vigente. Asimismo, el trabajo analiza la constitucionalización de instrumentos procesales de las inacciones legislativas, como asimismo las tensiones que pueden producirse entre el juez constitucional y el legislador en esta materia.
\end{abstract}

PALABRAS CLAVE: Jurisdicción constitucional; inconstitucionalidad por omisión.

ABSTRACT: The author analyzes the ever-present theme in comparative constitutional law on the establishing control of the constitutionality of legislative omissions, reviewing his emergence and its historical development, classification and taxonomy, the doctrine developed in the institution and in their concretion over the time, as also the current status of the institution of constitutional law in force. Furthermore, this work examines the constitutionalization of procedural instruments of legislative inaction, as are the tensions that can arise between the constitutional courts and the legislature in this matter.

KEY WORDS: Constitutional jurisdiction. Unconstitutionality by omission.

* Artículo recibido el viernes 25 de septiembre y aprobado el jueves 22 de octubre de 2009. 


\section{INTRODUCCIÓN}

La problemática relativa al control de la constitucionalidad de las omisiones legislativas ha sido considerada ${ }^{1}$ como uno de los más tormentosos y a la par fascinantes temas del Derecho constitucional de nuestro tiempo. No ha de extrañar que así se visualice si se atiende a los grandes retos que a la dogmática jurídica plantea la fiscalización de las inacciones del legislador.

El objeto de este trabajo es precisamente hacernos eco de algunos de tales retos, sin pretender agotar la compleja problemática que suscita el tema.

El necesario desarrollo de la Constitución por el legislador, el rol que debe asumir el poder legislativo en ese proceso de concreción constitucional y el margen de discrecionalidad en la determinación de los "tiempos" de desarrollo de que dispone el legislador, constituye el primero de los grandes retos a los que la dogmática constitucional debe tratar de dar una respuesta.

La tipología de las omisiones legislativas, con particularísima referencia a la clásica distinción entre omisiones absolutas y relativas, y las consecuencias que, en cuanto a su control, se anudan a uno y otro tipo, verdadero fulcro en el que apoyaría el Bundesverfassungsrichter Wessel, formulador de la célebre distinción, ${ }^{2}$ la trascendencia de su clasificación, constituye otro aspecto de trascendental relevancia llegado el momento de discernir la posible fiscalización de la quiescencia del poder legislativo y de precisar la vía más idónea de control.

La conceptualización, o si así se prefiere, la caracterización jurídica de las omisiones constitucionalmente relevantes y, por ello mismo, susceptibles de control, es otra cuestión dogmática de la mayor relevancia y en la que están lejos de ser pacíficas las posiciones de la doctrina, como revelan con meridiana claridad las supuestamente irreductibles divergencias entre las concepciones obligacionales y las normativistas, posicionamientos que en algunos casos, a nuestro modo de ver, son en gran parte deudores de la regulación constitucional dada al control de las omisiones legislativas por ciertos ordenamientos (piénsese sin más en las Constituciones portuguesa de 1976 y brasileña de 1988), si bien, a nuestro juicio, anticipémoslo ya, cabe buscar fórmulas de armonización llegado el momento de discernir cuáles son los presupuestos de una omisión inconstitucional con vistas a la caracterización jurídica de las mismas.

La búsqueda de técnicas decisorias con las que hacer frente al control de las omisiones supuestamente inconstitucionales es otro de los grandes retos que se ha planteado al constitucionalismo de la segunda postguerra, Contra lo que se hubiera podido pensar

1 Ferreria Mendes, Gilmar (2007). "O controle da omissâo inconstitucional”, en Jairo Gilberto Schäfer (organizador), Temas polêmicos do constitucionalismo contemporâneo (Florianópolis, Conceito Editorial), pp. 137 y ss.; en concreto, p. 138.

2 WeSSEL (1952). "Die Rechtsprechung des Bundesverfassungsgerichts zur Verfassungsbeschwerde", en Deutsches Verwaltungsblatt (DVBI), 67. Jahrgang, Heft 6, 15. März 1952, pp. 161 y ss.; en concreto, p. 164. 
en una aproximación superficial al tema, en bastantes países europeos no ha sido necesario esperar a que el constituyente articulara una vía específica de control, como sería el caso de la acción directa de inconstitucionalidad por omisión de la Constitución portuguesa de 1976, para que la fiscalización de las omisiones del legislador estuviese al alcance de los órganos titulares de la justicia constitucional. Lejos de ello, los Tribunales Constitucionales -el Bundesverfassungsgericht (BVerfG) y la Corte costituzionale serían los ejemplos paradigmáticos- con una creatividad digna del mayor encomio, han asumido desde fechas tempranas tal reto, que, contra lo que en ocasiones se cree, no se ha circunscrito ni mucho menos al control de las omisiones relativas, sino que también se ha proyectado hacia la fiscalización de las omisiones absolutas. Como es por entero lógico, a las diferentes vías procesales de control se han anudado efectos jurídicos diferentes, efectos que se nos presentan como muy plurales, incluso en países que, por simplificar, podríamos considerar que se ubican en un mismo sistema de fiscalización.

La mayor o menor idoneidad de los procedimientos de control abstracto y concreto y, en íntima vinculación con ello, el rol que al efecto pueden jugar los jueces ordinarios con vistas a llevar a cabo o, en su caso, a posibilitar el control de las omisiones relativas del legislador, es otro aspecto dogmático controvertido. Se trata por lo demás de una cuestión que si bien se ha suscitado muy particularmente en algún país concreto, como es el caso de Portugal, no ha dejado de plantearse en términos problemáticos por la doctrina de otros países.

En fin, los efectos de las decisiones estimatorias de la inconstitucionalidad de las inacciones del legislador es otro aspecto de la mayor trascendencia, innecesario es decirlo, en el que, particularmente en algunos países latinoamericanos, se han previsto fórmulas harto discutibles en cuanto que las mismas dejan abierta la posibilidad de que el juez constitucional se convierta en legislador, algo que nos parece por entero rechazable y de la mayor gravedad.

Son éstos algunos de los aspectos dogmáticos controvertidos de los que nos vamos a ocupar a continuación. Ni mucho menos agotan las cuestiones polémicas o susceptibles de plantear retos de interés para la dogmática jurídico-constitucional, pero sí nos parece que todos los puntos mencionados suscitan problemas y desafíos de la mayor relevancia.

Hemos de añadir algo más. Con las reflexiones que subsiguen en absoluto pretendemos tratar de esbozar una dogmática constitucional del control de las omisiones legislativas, y no ya tan sólo porque tal empresa requeriría de mucho mayor espacio del que razonablemente disponemos, sino porque nos hallamos en un terreno en el que una pretensión de tal género está llamada al seguro fracaso. La enorme heterogeneidad de las técnicas de fiscalización y la propia diversidad de los sistemas de justicia constitucional hacen muy difícil, por no decir que por entero imposible, el esbozo de una dogmática con pretensiones de generalidad. Hemos de limitarnos, pues, en buen número de los aspectos que vamos a tratar de desarrollar, a establecer un bosquejo y unas pautas tendenciales, que si pueden ser válidas para unos países, es difícil que lo 
sean para otros, y desde luego, a suscitar cuestiones problemáticas y a esbozar posibles soluciones, aun a sabiendas de su limitada validez. Pretender ir más allá creemos que sería una misión condenada a un fracaso seguro.

\section{EL LEGISLADOR ANTE EL DESARROLLO DE LA CONSTITUCIÓN}

I. El control de las omisiones del legislador entraña una ruptura frontal, podría decirse incluso que brutal, con los principios dogmáticos básicos sobre los que se construyó el Estado constitucional liberal, circunstancia que ya por sí sola haría conveniente una cierta prudencia por parte de los constituyentes a la hora de proceder a incorporar al acervo constitucional un instituto procesal tan rupturista como sería el de la acción de inconstitucionalidad por omisión legislativa.

Una perspectiva histórica siempre contribuye a la comprensión de las instituciones al visualizar el proceso evolutivo de su forja. Y desde tal óptica, puede ser de utilidad -con vistas a la constatación de la profundidad de los cambios que el control de las omisiones legislativas supone en la dogmática constitucional- recordar la visión que del legislador consagrara Blackstone en sus célebres Commentaires on the Laws of England (17651769), que puede quedar compendiada en su bien conocida afirmación: "that the power of Parliament is absolute and without control", visión que también quedaba perfectamente reflejada en la no menos célebre consideración de que el Parlamento "can do anything except transform a man into a woman and a woman into a man", cuya paternidad, como recordaba Cappelletti, ${ }^{3}$ ha sido atribuida tanto a De Lolme como a Bagehot. El propio Locke, en su Second Treatise on Civil Government, obra que, en algunas de sus ideas, impactaría notablemente sobre el Derecho constitucional norteamericano, ${ }^{4}$ consideraría al legislativo como el supremo órgano de la comunidad, si bien ello se asentaba en su relevante rol de salvaguarda de los derechos de los individuos, ${ }^{5}$ lo que venía a entrañar que en el ejercicio de sus funciones el legislativo no pudiera actuar como un poder arbitrario, circunstancia en la que se puede vislumbrar uno de los puntos de apoyo del rechazo a todo tipo de fiscalización de los actos legislativos.

El pensamiento revolucionario francés entronizará la supremacía del legislador por razones que no se alejan mucho de la concepción de Locke: la visión de la ley, y por lo mismo de quien la elabora, el legislador, como el instrumento más idóneo en pro de la libertad. A su vez, la inacción del legislador no suscitaría rechazo alguno por cuanto,

3 Cappelletti, Mauro (1971). Judicial Review in the Contemporary World (Indianapolis/Kansas, The Bobbs Merrill Company). City/New York, p. 31, nota 24.

4 En tal sentido, Edward S. Corwin (1963). The "Higher Law». Background of American Constitutional Law, Great Seal Books (Ithaca, New York, A Division of Cornell University Press), fifth printing, p. 67.

5 "The legislature -escribía Corwin (Ibidem, pp. 67-68)- is the supreme organ of Locke's commonwealth, and it is upon this supremacy that he depends in the main for the safeguarding of the rights of the individual. But for this very reason legislative supremacy is supremacy within the law, not a power above the law". 
en último término, casaba bien con los postulados subyacentes a la filosofía fisiocrática y liberal del laissez faire.

El influjo de esta concepción se prolongaría en el tiempo con notable fuerza, y en lo que ahora interesa, ya en el pasado siglo, se traduciría en el absoluto rechazo de cualquier tipo de control sobre las inacciones del legislador. La dogmática alemana de los primeros años del siglo XX nos ofrece significativos ejemplos de ello. Así, Anschütz, en 1912, escribía ${ }^{6}$ que las exigencias de los individuos frente al Estado como legislador, sea en orden a la realización, séalo a la omisión de un acto legislativo, pertenecen al género de los imposibles. También Jellinek se manifestaba en términos semejantes cuando escribía: "Das Individualansprüche an die Gesetzgebung unmöglich sind, kann als communis opinio gelten" (puede considerarse communis opinio que las pretensiones individuales a la legislación son imposibles). Y el propio Kelsen, en alusión a los preceptos que la Constitución de Weimar acogía en relación al contenido de futuras leyes, escribía: "Si el órgano legislativo expide una ley cuyos contenidos están prohibidos por la Constitución, se producen todas las consecuencias que de acuerdo con la Constitución van enlazadas a una ley inconstitucional. Sin embargo, si el órgano legislativo deja simplemente de expedir una ley prescrita por la Constitución, resulta prácticamente imposible enlazar a esa omisión consecuencias jurídicas". 8

No debe extrañar por todo ello que todavía en Weimar se rechazara mayoritariamente la vinculación del legislador a los derechos fundamentales; para él sólo valían como líneas orientativas o "proposiciones programáticas", en parte, a causa de su indeterminación material, pero más aún, como constata Böckenforde, ${ }^{9}$ por virtud de la idea de la soberanía estatal recibida del positivismo jurídico-público.

II. La Bonner Grundgesetz va a introducir un cambio de perspectiva en las relaciones legislativo/Constitución verdaderamente radical, que puede ejemplificarse en su conocida cláusula del art. I $^{\circ} .3$ : "Die nachfolgenden Grundrechte binden Gesetzgebung..." ("Los siguientes derechos fundamentales vinculan a la legislación..."). Esta norma encontraba su complemento en el art. 20.3 de la Grundgesetz, que no hacía sino ratificar la anterior previsión con una mayor amplitud de perspectiva, al proclamar ahora la vinculación del poder legislativo (literalmente, de la legislación, "die Gesetzgebung”) al ordenamiento constitucional ("an die verfassungsmässige Ordnung”). ${ }^{10}$

6 G. Anschütz (1993). Die Verfassungsurkunde für den preussischen Staat. Ein Kommentar für Wissenschaft und Praxis, 1912, p. 94. Cit. por BÖCKENFÖRDE, Ernst-Wolfgang (1993). Escritos sobre Derechos Fundamentales, Nomos Verlagsgesellschaft, Baden-Baden, p. 97.

7 Apud Trocker, Nicolò (1970). "Le omissioni del legislatore e la tutela giurisdizionale dei diritti di libertà (Studio comparativo sul diritto tedesco)”, en Archivio Giuridico "Filippo Serafini”, vol. CLXXVIII, fascicoli 1-2,Gennaio/Aprile 1970, pp. 88 y ss.; en concreto, p. 108, nota 41.

8 Kelsen, Hans (1949). Teoría General del Derecho y del Estado, Imprenta Universitaria, México, p. 275.

9 BÖCKENFÖRDE, Ernst (1993). Escritos sobre Derechos Fundamentales (Baden-Baden, Nomos Verlagsgesellschaft, p. 97).

10 Recordemos que el precepto se completa con la sujeción de los poderes ejecutivo y judicial a la ley y al Derecho. A tenor del art. 20.3 GG: "Die Gesetzgebung ist an die verfassungsmässige Ordnung, die vollziehende Gewalt und die Rechtsprechung sind an Gesetz und Recht gebunden". 
A partir de esta vinculatoriedad del legislador por la Ley Fundamental se iba a suscitar la cuestión de cuál era la situación en que se encontraba el poder legislativo ante los mandatos constitucionales a él dirigidos. ¿Podía hablarse de la plena discrecionalidad del legislador o, por contra, de un deber de legislar vinculante y, caso de omisión, susceptible de un posible control en sede constitucional?

Denninger se referiría a este respecto a la larga lista de mandatos al legislador que la Grundgesetz (al igual que otras muchas cartas constitucionales) acogía, mandatos en unos casos explícitos, en otros implícitos, en ocasiones condicionales, y otras veces incondicionales. Para el Profesor de Frankfurt am Main, esos mandatos habían de verse más que como una mera apelación ético-política ("einen politisch-ethischen Appell"), como una obligación jurídica vinculante para el órgano legislativo ("rechtsverbindliche Pflichten der gesetzgebenden Organe”). ${ }^{11}$ También Pestalozza considerará que la inacción del legislador es relevante constitucionalmente, visualizándola como tal cuando entrañe la inobservancia de un deber constitucional de legislar. Para el Profesor de la "Freien Universität Berlin”, “das Unterlassen des Gesetzgebers ist verfassungswidrig, wenn die Verfassung ein Handeln des Gesetzgebers fordet" 12 (la omisión del legislador es inconstitucional cuando la Constitución le exige una actuación). A partir de la idea expuesta, que se traduce en que la comprobación de si el legislador ha incurrido en inconstitucionalidad por omisión presupone la constatación de la existencia de un correspondiente mandato constitucional de actuación ("einen entsprechenden Verfassungsauftrag zum Handeln"), Pestalozza viene a diferenciar dos tipos de mandatos constitucionales: los mandatos sustituibles y los insustituibles (vertretbaren und unvertretbaren Aufträgen). Tratándose de un mandato sustituible, el Tribunal Constitucional Federal (Bundesverfassungsgericht, BVerfG) no puede determinar la inconstitucionalidad de la omisión del legislador ("die verfassungswidrigkeit des gesetzgeberischen Unterlassen”). Para Pestalozza, en los recursos de queja constitucional (Verfassungsbeschwerde) frente a resoluciones judiciales que se sustenten en el incumplimiento ("Nichterfüllung") de mandatos de este tipo, el BVerfG ha de asignar a los propios tribunales ordinarios el cometido de implementar a través de la concreción (Konkretisierung) el mandato constitucional. Por contra, cuando la norma de la Grundgesetz, no obstante la falta de mediación del legislador, despliega una eficacia suficiente ("hinreichende Wirkungskraft entfaltet"), los tribunales tienen que aplicarla inmediatamente ("haben die Gerichte sie unmittelbar anzuwenden"), no pudiendo objetar que el legislador no ha desarrollado su mandato. Ahora bien, en este tipo de mandatos, esto es, en los "vertretbaren Verfassungsaufträgen", el transcurso de un cierto largo período de tiempo ("eine gewisse Zeit lang”) se traduce en que la omisión

11 DenNinger, Erhard. (1966). "Verfassungsauftrag und gesetzgebende Gewalt”, en Juristenzeitung (JZ), 21. Jahrgang, Nummer 23/24, 9. Dezember 1966, pp. 767 y ss.; en concreto, p. 772.

12 Pestalozza, Christian (1976). “Noch Verfassungsmässige» und "bloss Verfassungswidrige» Rechtslagen” (Zur Feststellung und Kooperativen Beseitigung verfassungsimperfekter Zustände), enBundesverfassungsgericht und Grundgesetz (Festgabe aus Anlass des 25 jährigen Bestehens desBundesverfassungsgericht), herausgegeben von STARCK, Christian (1976), Erster band (primer volumen), J.C.B. Mohr, (Tübingen, Paul Siebeck), pp. 519 y ss.; en concreto, p. 526. 
legislativa constitucional pasa a convertirse en inconstitucional. Cuando se trate de mandatos constitucionales insustituibles ("unvertretbaren Verfassungsaufträgen”), al contrario de los supuestos precedentes, Pestalozza entiende que "die Gerichte Können hier den Gesetzgeber, der säumig ist, nicht vertreten" (los tribunales no pueden sustituir al legislador moroso); por eso tiene que declararse, en caso necesario, la inconstitucionalidad de su inactividad. ${ }^{13}$

Con una perspectiva general, puede sostenerse que la mayor parte de la doctrina que se ha pronunciado al respecto se ha decantado por relativizar la discrecionalidad del legislador, concepto por lo demás vinculado en su origen al Derecho administrativo, que ha ido siendo sustituido en la jurisprudencia del $B V e r f G$ por el de libertad de configuración del legislador ("gesetzgeberischen Freiheit"). ${ }^{14}$

Es cierto que otros sectores doctrinales, más matizadamente, han seguido defendiendo la mencionada libertad del legislador. Es el caso, por ejemplo, de Lerche, quien entiende que los mandatos constitucionales (Verfassungsbefehle) no pueden cambiar en lo esencial la imagen dada por la Constitución, es decir, y en lo que ahora interesa, la libertad de iniciativa y de configuración del legislador, si bien, matiza Lerche de inmediato, ${ }^{15}$ en una metáfora que nos trae a la memoria la extraordinaria pintura del gran romántico alemán Caspar David Friedrich (1774-1840), aquellos mandatos son algo más que simples arrecifes ("Klippen") que se adentran al mar de la libertad de configuración del legislador ("das Meer der gesetzgeberischen Freiheit"). En otro momento, Lerche aún matizará más, al señalar que el legislador ni es soberano, ni se ha convertido en un mero poder ejecutivo. Su posición sólo se deja determinar de modo relativo ("Seine Stellung lässt sich nur relativ bestimmen”), según los grupos de directivas constitucionales de que se trate, o lo que viene a ser igual, según los ámbitos constitucionales en cuestión. ${ }^{16}$

En una dirección próxima a la de los primeros autores mencionados se ubica Gomes Canotilho, quien ha tratado con detenimiento el tema. Desde el primer momento, el Profesor de Coimbra defendió la reducción de la existencia de una omisión inconstitucional a los casos en que la norma constitucional impusiera un deber concreto de actuación, deber que, en cualquier caso, se expandía enormemente en el texto inicial de la Constitución portuguesa de $1976 .{ }^{17}$ Ya en referencia al texto constitucional portugués reformado en 1982, el propio autor ha significado que las omisiones legislati-

13 Ibidem, p. 527.

14 Cfr. al efecto, Hans-Peter SCHNEIDER (1982). "Jurisdicción constitucional y separación de poderes”, en Revista Española de Derecho Constitucional, n ${ }^{\circ}$ 5, Mayo/Agosto 1982, pp. 35 y ss.; en concreto, p.55.

15 LERCHE, Peter (1965). "Das Bundesverfassungsgericht und die Verfassungsdirektiven. Zu den "nicht erfüIlten Gesetzgebungsaufträgen"”, en Archiv des öffentlichen Rechts (AöR), 1965, pp. 341 y ss.; en concreto, p. 355.

16 Ibidem, pp. 371-372.

17 Gomes Canotilho, José Joaquim (1982). Constituiçâo dirigente e vinculaçâo do legislador. Contributo para a compreensâo das normas constitucionais programáticas, (Coimbra, Coimbra Editora), p. 351. 
vas inconstitucionales derivan del incumplimiento de una imposición o mandato constitucional de legislar en sentido estricto, esto es, del incumplimiento de normas que, de forma permanente y concreta, vinculan al legislador a la adopción de medidas legislativas de concreción o desarrollo constitucional ("medidas legislativas concretizadoras da constituiçâo"). Ciertamente, ese no será el caso de las que Canotilho denomina "normas-fim ou normas-tarefa", abstractamente impositivas. ${ }^{18}$ En definitiva, a la inacción del legislador ante las "ordems de legislar" podrá anudarse una declaración de inconstitucionalidad, lo que no sucederá respecto de las "normas-tarefa”.

En resumen, la doctrina que con más detenimiento se ha ocupado del tema admite generalizadamente que determinadas normas constitucionales impelen al legislador a actuar en desarrollo y concreción de la Constitución, pudiendo generar la pasividad del legislador una omisión inconstitucional. Pero, más allá de ello, el deber constitucional de legislar, como ha interpretado en Alemania el $B V e r f G$, puede derivar no sólo de mandatos concretos contenidos en la Grundgesetz, sino también de principios identificados en el proceso de interpretación de la Norma suprema, ${ }^{19}$ lo que aún abre en mayor medida el campo de posibilidades del instituto analizado.

III. La búsqueda de las fuentes del deber de legislar no puede, sin embargo, quedar estrictamente circunscrita a una visión que se limite a atender a la heterogénea tipología de las normas constitucionales, extrayendo este deber que recae sobre el poder legislativo tan sólo de la estructura y configuración de la norma constitucional.

Analizada la cuestión desde esa óptica de los tipos normativos, nos vamos a centrar ahora en una visión diferente, de sesgo material, en la que resulta obligado prestar atención preferente a los derechos constitucionales, pues es indiscutible que en ellos encontramos, por así decirlo, fuentes privilegiadas del deber de legislar, lo que no es sino la resultante obligada de la centralidad de los derechos en los ordenamientos constitucionales de nuestro tiempo.

Häberle, en su obra ya clásica, Die Wesensgehaltgarantie des Art. 19 Abs. 2 Grundgesetz, consideraría que todas las disposiciones de la Grundgesetz sobre derechos fundamentales eran susceptibles y estaban necesitadas, por un lado, de una delimitación negativa, y por otro, de la conformación y precisión de contenido por la ley. El legislador está para ello al servicio del correspondiente derecho fundamental afectado. La Constitución presupone su actividad como evidente y, por tanto, no sólo como permitida, sino también como ordenada. ${ }^{20}$ Para el Profesor de Bayreuth, la interven-

18 Cfr, al efecto, Gomes Canotilno J.J. (2002). Direito Constitucional e Teoría da Constituiçâo, $5^{\mathrm{a}}$ ediçâo, Almedina, Coimbra, pp. 1021-1022.

19 En tal sentido, Ferreira Mendes, Gilmar (2005). Jurisdiçâo Constitucional (O controle Abstrato de Normas no Brasil e na Alemanha), $5^{\text {a }}$ ediçâo, Editora Saraiva, Sâo Paulo, p. 274.

20 HäBerle, Peter (1962). Die Wesensgehaltgarantie des Art. 19 Abs. 2 Grundgesetz, Karlsruhe, $1^{\text {a }}$ ed., 1962. Manejamos la versión española. HÄBERLE, Peter. (2000). La garantía del contenido esencial de los derechos fundamentales en la Ley Fundamental de Bonn (Una contribución a la concepción institucional de los derechos fundamentales y a la teoría de la reserva de ley), (Madrid, Dykinson), p. 169. 
ción del legislador en el ámbito de los derechos fundamentales es tanto más apremiante cuanto más intensa sea la relación social de la correspondiente libertad. ${ }^{21} \mathrm{La}$ Grundgesetz - añade Häberle ${ }^{22}$ - necesita a la legislación como medium y como mediadora respecto a la realidad social, siendo a través de la legislación como la Ley Fundamental alcanza "vigencia real", pues sin ella, se queda en un "nivel ideal" de validez sólo formal. En definitiva, los derechos fundamentales sólo pueden cumplir su función social a través de la legislación, lo que deja meridianamente clara la trascendencia que para la vigencia de la Constitución en el ámbito de los derechos fundamentales tiene la intervención del legislador. En coherencia con ello, el incumplimiento del mandato de intervención que pesa sobre el legislador afecta a la propia vigencia constitucional, generando situaciones en la vida social alejadas, cuando no lisa y llanamente contrapuestas, a los mandatos del constituyente, o propiciando en las relaciones jurídicas la vigencia de normas implícitas en franca contradicción con la Constitución.

El BVerfG no iba a tardar mucho tiempo en abordar la cuestión que ahora nos ocupa. Es cierto que en una decisión de 19 de diciembre de 1951 rechazó admitir un recurso de queja constitucional (Verfassungsbeschwerde) contra una omisión del legislador relacionada con un derecho fundamental, al considerar que los preceptos de la Grundgesetz no aseguraban al ciudadano cualquier pretensión a una actividad legislativa susceptible de ser recurrida, caso de omisión, a través de tal vía procesal, pero, como posteriormente se verá, los años 1957 y 1958 marcarán un punto de inflexión frente a tal interpretación.

Por lo demás, el deber constitucional de legislar puede dimanar también del llamado "deber de protección" (Schutzpflicht), que obliga al Estado a actuar en defensa y protección de ciertos valores y derechos como la vida y la integridad física, sobre todo, frente a agresiones llevadas a cabo por terceros. Innecesario es decir que el verdadero protagonismo lo asumen aquí los derechos fundamentales, que se visualizan como deberes de protección, lo que, a juicio de Böckenförde, ${ }^{23}$ resulta una consecuencia necesaria del carácter de los derechos fundamentales como normas objetivas de principio y decisiones axiológicas, pudiéndonos incluso plantear si el "deber de protección”, abstracción hecha de su relativamente tardío despuntar, no representa el concepto central de la dimensión jurídico-objetiva de los derechos fundamentales.

Klein, quien se ha ocupado con algún detalle de la jurisprudencia del $B V e r f G$ en torno al "deber de protección", ${ }^{24}$ ha llegado a contraponer la tradicional función negativa de los derechos (" "negatorische" Funktion der Grundrechte”), esto es, su visión como libertades negativas o, si se prefiere, como garantías de defensa frente al propio Estado, a la innovadora función de los derechos que ahora nos ocupa: "die grundrechtliche Schutzpflicht". ${ }^{25}$

1 HäBerLe, Peter (1962), p. 170.

22 HÄBERLE, Peter (1962), p. 172.

23 BÖCKENFÖRDE, Ernst-Wolfgang (1993), pp. 114-115.

24 Klein, Eckart (1989). "Grundrechtliche Schutzpflicht des Staates", en Neue Juristische Wochenschrift (NJW), 42. Jahrgang, Heft 27, 5. Juli 1989, pp. 1633 y ss.; en especial, pp. 1634-1635.

25 KleIN, Eckart (1989), p. 1633. 
Análoga tesis en relación a los derechos fundamentales (grundrechte) ha mantenido Scholz, ${ }^{26}$ quien se ha referido a la notable relevancia en la doctrina del $B V e r f G$, en lo que ahora interesa, de la llamada "teoría de la sustancialidad" (Wesentlichkeitstheorie), de conformidad con la cual, el $B V e r f G$ ha entendido que el mandato prioritario que la Grundgesetz hacía recaer sobre el legislador en este ámbito era la protección de los derechos fundamentales, lo que, es obvio, no sólo es relevante en el plano de la delimitación atributiva entre el legislativo y el ejecutivo, sino que también lo es, y mucho, respecto a la cuestión que venimos tratando, esto es, la asunción por el legislador de un deber de legislar.

En su extraordinariamente relevante jurisprudencia, el $B V e r f G$ no sólo ha reconocido que los derechos fundamentales aseguran a toda persona un derecho de defensa frente a intervenciones estatales $(A b \text { wehrrecht })^{27}$ y unos eventuales derechos a prestaciones positivas (Leistungsrecht), sino también este derecho de protección a que venimos refiriéndonos, cuyo correlato obvio es el deber de protección que recae sobre los poderes públicos y, de modo muy particular, sobre el poder legislativo, deber que el Bundesverfassungsgericht ha sustentado básicamente en el art. $2^{\circ} .2$ de la Grundgesetz. ${ }^{28}$

Por otro lado, el $B V e r f G$ ha identificado asimismo como fundamento del deber constitucional de legislar, el "deber general de adecuación” ("allgemeiner Nachbesserungsvorbehalt”), que impone al legislador la obligación de actuar de forma protectora y constructiva en el ámbito de los derechos fundamentales. Un buen ejemplo de una norma constitucional necesitada de esta adecuación y desencadenante por lo mismo de un deber del legislador lo podríamos encontrar en el art. $6^{\circ} .5 \mathrm{GG}$, de conformidad con el cual, la legislación ha de otorgar a los hijos naturales ("den unehelichen Kindern") las mismas condiciones ("die gleichen Bedingungen”) para su desarrollo físico y mental y su posición en la sociedad ("und ihre Stellung in der Gesellschaft") que a los hijos matrimoniales ("den ehelichen Kindern”). Esta disposición daría pie a una conocidísima sentencia del BVerfG, de 29 de enero de 1969.

También en relación con el mencionado "deber de adecuación", se suele citar la Sentencia de 8 de agosto de 1978, relativa al reactor nuclear de Kalkar ("Kalkar Urteil”), considerada como paradigmática en la identificación de tal deber. En ella, el Tribunal Constitucional reconoció que en virtud de los nuevos desarrollos científicos, el legislador estaba constitucionalmente obligado a un reexamen en relación al uso pacífico de la energía atómica. Analizando diferentes recursos de queja constitucional interpuestos por habitantes de la región próxima a las instalaciones nucleares, el $B V e r f G$ resolvió que: "En el supuesto de que se constaten indicios de peligro provenientes de

26 Scholz, Rupert (2002). "Alemania: cincuenta años de la Corte Constitucional Federal”, en Anuario de Derecho Constitucional Latinoamericano, Konrad Adenauer Stiftung, 2002, pp. 57 y ss.; en concreto, p. 64.

27 "Grundrechte -escribe Klein (en Ibidem, p. 1633)- sind staatsgerichttete Abwehrrechte".

28 El art, $2^{\circ} .2$ GG reconoce a cada uno ("Jeder") el derecho a la vida ("das Recht auf Leben") y a la integridad física ("und körperliche Unversehrtheit”) y declara de inmediato que la libertad de la persona ("Freiheit der Person”) es invulnerable ("unverletzlich”). 
reactores nucleares del tipo "Schneller Brüter» (...), el legislador está obligado a promulgar las nuevas medidas que se requieran”. Un pronunciamiento en similar dirección sería el de 14 de enero de 1981 , sobre la polución sonora causada por los aviones. En cierto modo, podría verse en la referida jurisprudencia un ejemplo reconducible a lo que Stern identifica ${ }^{29}$ como mandatos para la mejora a posteriori y la corrección de leyes en los supuestos de prognosis errónea o de modificación de las circunstancias determinantes.

IV. Cuanto se ha expuesto hasta aquí creemos que deja meridianamente claro el brutal cambio que el legislador ha experimentado en su relación con la Constitución. Podrían aportarse, desde luego, nuevos argumentos al respecto.

Los derechos socio-económicos dan pie para ello, pues es sobradamente conocido que, para ser efectivos, demandan una intervención activa de los poderes públicos, con frecuencia prolongada en el tiempo. A diferencia de los derechos tradicionales o de libertad, los derechos sociales no pueden ser simplemente conferidos al individuo, pues exigen una acción permanente del Estado, que debe prestar su asistencia financiera y derribar las barreras sociales y económicas que, en ocasiones, obstan su optimización; en definitiva, los poderes públicos han de asegurar la realización de los programas de desarrollo social que constituyen la base de estos derechos y de las expectativas por ellos engendradas.

La trascendencia de los derechos sociales va a ser muy grande, traspasando de largo su propio ámbito. Como señalara Alexy, ${ }^{30}$ la libertad jurídica para hacer $u$ omitir algo sin la libertad fáctica (real), esto es, sin la posibilidad de elegir entre lo permitido, carece de todo valor. Y bajo las condiciones de la moderna sociedad tecnológica e industrial, la libertad fáctica de un gran número de titulares de derechos fundamentales no encuentra su sustrato material en un "ámbito vital dominado por ellos", sino que depende esencialmente de actividades estatales.

La transformación del Estado que todo ello ha supuesto ha sido enorme, incidiendo sobre el rol de todos los poderes y, de modo muy particular, sobre el que corresponde a los órganos jurisdiccionales y a los Tribunales constitucionales. Ya Cappelletti puso de relieve ${ }^{31}$ el significativo cambio del rol de los jueces, cuya actividad había de adoptar un aspecto nuevo en su modo de interpretar las leyes con vistas a dar un contenido concreto a la legislación y a los derechos sociales, lo que había de conducir a una mayor discrecionalidad y a una más significativa participación en la creación del

29 Stern, Klaus (1987). Derecho del Estado de la República Federal Alemana, (Madrid, Centro de Estudios Constitucionales), p. 225.

30 AlEXY, Robert (1993). Teoría de los derechos fundamentales, (Madrid, Centro de Estudios Constitucionales), pp. 486-487.

31 Cappellettr, Mauro (1990). "Des juges législateurs?", en la obra recopilatoria de trabajos del propio autor, Le pouvoir des juges, (Paris, Economica/Presses Universitaires d'Aix-Marseille), pp. 23 y ss.; en concreto, pp. 44-45. 
Derecho. Desde otra óptica, Michelmann ha hablado de una "egalitarian revolution" en los tribunales, ${ }^{32}$ en sintonía con la relevancia que el propio autor cree que se debe otorgar a los derechos de naturaleza social, que compendiaría en lo que tildó de "the welfare-rights thesis". ${ }^{33}$

A la vista de lo expuesto, se puede comprender bien, en relación a lo que ahora interesa, la conveniencia de establecer, a través de una u otra vía procesal, cauces encaminados a la fiscalización de las omisiones del legislador relevantes constitucionalmente. En tal dirección, Alexy, con apoyo en la jurisprudencia del $B V e r f G$, ha podido afirmar que en modo alguno un Tribunal Constitucional es impotente frente a un legislador inoperante. ${ }^{34}$ Y Vieira de Andrade, desde otra óptica, en un libro ya clásico en Portugal, ${ }^{35}$ ha señalado que la protección jurídico-constitucional de los derechos sociales en el nivel legislativo reposa principalmente en nuestro vecino país en el mecanismo de la fiscalización abstracta de la inconstitucionalidad por omisión.

V. El profundísimo cambio que se ha producido en el constitucionalismo posterior a la Segunda Guerra Mundial en la relación que el legislador mantiene respecto a la Constitución creemos que queda puesto de relieve tras la exposición precedente. La antaño absoluta discrecionalidad del poder legislativo ha dado paso a una libertad de configuración que debe en todo caso de armonizarse con la vinculatoriedad de los mandatos constitucionales. No es que no se pueda seguir manteniendo su libre capacidad de configuración, pero es claro que ésta conoce manifestaciones graduales diferenciadas. Como señalara Kalkbrenner, ${ }^{36}$ si hay un mandato constitucional, el legislador queda comprometido a llevarlo a cabo y a promulgar la ley conveniente o las leyes necesarias. Cuando se produce esta situación, la ejecución del mandato al legislador (a la legislación, en la dicción original: "der Erfullung des Gesetzgebungsauftrag”) no depende de la libre voluntad del legislador (“liegt nicht im freien Belieben des Gesetzgebers”).

También entre la doctrina italiana hay una posición muy arraigada en el sentido de que la discrecionalidad del legislador debe ceder en ciertos casos. Mortati ejemplifica perfectamente esta visión: "La discrezionalità del legislatore -escribía el gran maestro italiano en $1970,{ }^{37}$ deve cedere di fronte a prescrizioni costituzionali che gli impongo-

32 "A notable feature in the Court's "egalitarian revolution", many commentators suggest, is the emergence of special judicial hostility towards official discrimination, be it de jure or de facto, according to pecuniary circumstance". MichelmanN, Frank I.: "The Supreme Court 1968 Term. Foreword: On Protecting the Poor Through the Fourteenth Amendment", en Harvard Law Review, volume 83, 1969-1970, pp. 7 y ss.; en concreto, p. 19.

33 Cfr. al respecto, Frank I. Michelmann (1979). "Welfare Rights in a Constitutional Democracy", en Washington University Law Quarterly, volume 1979, number 3, Summer 1979, pp. 659 y ss.

34 Robert Alexy: Teoría de los Derechos Fundamentales, op. cit., p. 496.

35 Vieira de Andrade, José Carlos (2007). Os Direitos Fundamentais na Constituiçâo Portuguesa de 1976, $3^{\mathrm{a}}$ ediçâo, $2^{\text {a }}$ reimpressâo (Coimbra, Almedina), p. 413.

36 Kalkbrenner, Helmut (1963). "Verfassungsauftrag und Verpflichtung des Gesetzgebers", en Die Öffentliche Verwaltung (DÖV), 16. Jahrgang, Heft 2, pp. 41 y ss.; en concreto, p. 43.

37 MortatI, Costantino (1972). "Appunti per uno studio sui rimedi giurisdizionali contro comportamenti omissivi del legislatore”, en la obra del propio autor (1972), Problemi di Diritto pubblico nell'attuale 
no l'obbligo di provvedere alla tutela di diritti posti come fondamentali (...). Non varrebbe invocare in contrario un principio di gradualità che conferirebbe al legislatore piena libertà di scelta del momento nel quale realizzare gli imperativi costituzionali”. Crisafulli no es menos rotundo en relación a la cuestión que nos ocupa: "anche la mera omissione - escribe ${ }^{38}$ - può essere dichiarata costituzionalmente illegittima ed all'organo rimasto inattivo può essere imposto l'obbligo di compiere una determinata attività". No obsta a lo anterior, a juicio del gran constitucionalista italiano, que ningún término o plazo haya sido constitucionalmente establecido, pues "la facoltà, che in tal caso deve ritenersi attribuita al legislatore, di graduare nel tempo secondo criteri di oppotunità politica i propri interventi incontra pur sempre un limite, oltrepassato il quale la non attuazione diventa (...) inadempienza vera e propria”. En fin, quien fuera presidente de la Corte costituzionale, Livio Paladin, hace más de medio siglo, ya concebía la discrecionalidad del legislador como libertad limitada. ${ }^{39}$

Aún en Francia, en donde es bien sabido el rol estelar que siempre ha correspondido a la ley, el cambio de perspectiva ha sido más que notable. En pocas palabras, Georges Vedel, en su condición de ponente ("rapporteur") de la importante Decisión del Conseil constitutionnel $\mathrm{n}^{\circ}$ 85-197 DC, de 23 de agosto de 1985, "Évolution de la Nouvelle Calédonie (II)", condensaría brillantemente tal cambio: "La loi votée -puede leerse en el considerando ${ }^{\circ} 27$ de dicha decisión- qui n'exprime la volonté générale que dans le respect de la Constitution".

VI. Llegados aquí es necesario apostillar que el legislador en modo alguno se encuentra respecto a la Constitución en la misma relación en que se halla el poder reglamentario respecto de la ley. El Tribunal Constitucional español ha tenido oportunidad de aludir a ello, en términos que bien pueden ser recordados: “...no es la misma la relación que existe entre Constitución y ley que la que media entre ésta y el reglamento. El legislador no ejecuta la Constitución, sino que crea Derecho con libertad dentro del marco que ésta ofrece, en tanto que el ejercicio de la potestad reglamentaria se opera "de acuerdo con la Constitución y las leyes" (art. $97 \mathrm{CE})$ y el Gobierno no puede crear derechos ni imponer obligaciones que no tengan su origen en la ley de modo inmediato o, al menos, de manera mediata, a través de la habilitación". ${ }^{40}$

La Constitución es un marco normativo lo suficientemente amplio como para que dentro del mismo quepan diferentes opciones de desarrollo, que el legislador, que actualiza permanentemente la voluntad soberana del pueblo, está legitimado para

esperienza costituzional repubblicana (Raccolta di Scritti-III), Giuffrè, Milano, pp. 923 y ss.; en concreto, p. 992. Artículo inicialmente publicado en II Foro Italiano, 1970, V, pp. 153 y ss.

38 CrISAfull, Vezio. (1977). "Giustizia costituzionale e potere legislativo", en Aspetti e tendenze del Diritto costituzionale. Scritti in onore di Costantino Mortati, Giuffrè, Milano, vol. $4^{\circ}$, pp. 129 y ss.; en concreto, p. 143.

39 Paladin, Livio. (1956). "Osservazioni sulla discrezionalità e sull'eccesso di potere del legislatore ordinario”, en Rivista trimestrale di Diritto pubblico, anno VI, 1956, pp. 993 y ss.; en concreto, p. 1025.

40 Sentencia del Tribunal Constitucional (STC) 209/1987, de 22 de diciembre, fundamento jurídico (fund. jur.) $3^{\circ}$. 
adoptar. Esto se manifiesta de múltiples modos. Y así, por poner un ejemplo, aunque al legislador le está vedado todo trato discriminatorio, su libertad de configuración y la correlativa "prerrogativa de estimación" ("Einschätzungsprärogative") a la que alude Schneider, ${ }^{41}$ se traducen en que el legislador esté llamado no sólo a elegir aquellas situaciones objetivas a las que quiere vincular iguales o desiguales efectos jurídicos, sino también a determinar las características que han de ser comparadas y a delimitar, hasta la frontera de lo arbitrario, el ámbito de las diferencias. Esta frontera de la arbitrariedad es permeable hasta un cierto punto: sólo cuando las decisiones legislativas llegan a un nivel de irracionalidad evidente, se consideran inconstitucionales.

En definitiva, la sujeción del legislador a la Constitución no impide en modo alguno la libertad de configuración de que el mismo goza, que se proyecta no sólo sobre el contenido a dar a la norma de desarrollo constitucional, sino también sobre el tiempo, esto es, sobre el momento en que llevar a cabo dicho desarrollo, pero ni uno ni otro aspecto quedan sujetos a la libérrima capacidad decisoria del poder legislativo, pudiendo, desde luego, ser objeto de control en sede constitucional. Siendo ello así, debe precisarse que en modo alguno ese control puede propiciar la sustitución del legislador por el juez constitucional, algo sobre lo que volveremos más adelante, pero que, anticipémoslo ya, ha sido posibilitado por algunos ordenamientos jurídicos latinoamericanos.

\section{TIPOLOGÍA DE LAS OMISIONES LEGISLATIVAS}

I. Fue Wessel, juez del BVerfG, quien en 1952, muy poco después por tanto de que el Tribunal Constitucional Federal iniciara sus tareas, en un trabajo ya clásico en el que abordó el estudio de la jurisprudencia del BVerfG sobre el Verfassungsbeschwerde, vino a sentar las bases de la más conocida y reiterada tipología de las omisiones legislativas.

Wessel niega por principio que se produzca una lesión de derechos a través de una omisión absoluta del legislador ("eine Grundrechtsverletzung durch ein absolutes Unterlassen des Gesetzgebers”), que innecesario es decir que se da cuando el poder legislativo ha omitido la norma legislativa constitucionalmente requerida. De ahí que se haga eco de inmediato de que el $B$ VerfG había rechazado por improcedente ("unzulässig") un recurso de queja constitucional a cuyo través se impugnaba una lesión del derecho fundamental al libre desarrollo de la personalidad ("eine Verletzung des Grundrechts auf freie Entfaltung der Persönlichkeit”) con base en que el legislador no había implementado una ley a cuyo través todos tuvieran la posibilidad de plantear una pretensión adecuada a este derecho. En tal caso, ${ }^{42}$ argumentará Wessel, ${ }^{43}$ se trataría no de una cuestión puramente jurídica, sino de una cuestión política ("eine politische Frage").

\footnotetext{
41 Hans-Peter SCHNEIDER (1982), p. 51.

42 Wessel se está refiriendo, como creemos queda claro si se atiende a lo ya expuesto, a la Sentencia dictada por el BVerfG con fecha de 19 de diciembre de 1951.

43 WESSEL: “Die Rechtsprechung des Bundesverfassungsgerichts zur Verfassungsbeschwerde”, op. cit., p. 164.
} 
Se hará eco a renglón seguido el mencionado juez constitucional de la omisión relativa (relatives Unterlassen), señalando que se reprocha al legislador una lesión de derechos fundamentales a través de una omisión relativa, cuando se le imputa haber regulado tan sólo ciertas pretensiones jurídicas de algún grupo, con lesión del principio de igualdad ("unter Verletzung des Gleichheitsgrundsatzes"). En tal caso, para Wessel, el recurso de queja constitucional se dirige en realidad no contra la omisión, sino frente a una actuación positiva del legislador ("die Verfassungsbeschwerde in Wahrheit nicht gegen eine Unterlassung, sonder gegen ein positives Handeln des Gesetezgebers"). En este supuesto, el recurso de queja, caso de ser adecuadamente fundamentado, podría conducir no sólo a la fiscalización de la actuación del legislador, que a través de la "omisión de participación de un determinado grupo" ("durch Unterlassung der Beteiligung einer bestimmten Gruppe") ha lesionado el art. $3^{\circ}$ de la Grundgesetz, ${ }^{44}$ sino también a la declaración de inconstitucionalidad ("die Feststellung der Verfassungswidrigkeit”), lo que tendría como consecuencia la nulidad de la regulación parcial ("die Nichtigkeit der gesetzlichen "Teilregelung"”). La conclusión de Wessel es inequívoca: "In derartigen Fällen läge stets eine unmittelbare Grundrechtsverletzung durch den Gesetzgeber vor") (en este tipo de casos habría siempre una lesión inmediata de los derechos fundamentales a través del legislador). ${ }^{45}$

La conclusión de todo lo expuesto es que para Wessel las omisiones absolutas del legislador (Absolutes Unterlassen des Gesetzgebers) son aquellas en las que hay una total falta de desarrollo por parte del mismo de una disposición constitucional, mientas que las omisiones relativas (relatives Unterlassen) presuponen una regulación parcial que, al omitir del goce del derecho a determinados grupos de personas, vienen a entrañar una violación del principio de igualdad. En la formulación del mencionado autor parece quedar claro que el mayor interés de esta tipología dual hay que buscarlo en las consecuencias que se anudan a uno u otro tipo de omisión: el carácter fiscalizable de la omisión relativa frente a la no fiscalización de la omisión absoluta.

II. La tipología de Wessel tendría un enorme eco doctrinal, bien que las posiciones de los autores no siempre fueran coincidentes, encontrándose entre ellas posturas bastante críticas. Así, por poner algún ejemplo, Mortati consideraría que la clasificación formulada por el juez constitucional alemán se hallaba necesitada de precisión desde un doble punto de vista: en primer lugar, porque la ausencia de toda disciplina legal para el desarrollo de un principio constitucional no era, per se, suficiente para

44 Recordemos que, a tenor del art. 3.1 GG: "Alle Menschen sind vor dem Gesetz gleich" ("Todos los hombres son iguales ante la Ley”). Como señalara Rupp, el principio general de la igualdad del párrafo primero del art. $3^{\circ}$ de la Grundgesetz adquiere su mayor alcance en el campo de la actividad del Estado relativa al otorgamiento de alguna cosa por él, por lo tanto, en el terreno de la preservación de las condiciones de existencia y de las prestaciones de carácter social en su más amplio sentido. En definitiva, el principio de igualdad se dirige ante todo al legislador. Hans G. Rupp: "El Tribunal Constitucional Federal Alemán”, (dentro de la temática relativa al objeto y alcance de la protección de los derechos fundamentales), en la obra colectiva, (1984), Tribunales Constitucionales y Derechos Fundamentales, CEC, Madrid, pp. 319 y ss.; en concreto, p. 341.

45 WESSEL: "Die Rechtsprechung des Bundesverfassungsgerichts zur Verfassungsbeschwerde", op. cit., p. 164. 
considerar inadmisible una acción dirigida a poner remedio a tal situación, "non potendo escludersi che la norma impugnabile si ricavi dal sistema”, y en segundo término, porque desarrollos parciales de la Carta constitucional son perseguibles ante la justicia constitucional ("in giudizio di costituzionalità") no en el único caso de que se opongan al principio de igualdad, sino también cuando de ello se derive una lesión de "qualsiasi altra direttiva posta dalla medesima". ${ }^{46}$

Muy crítico frente a las omisiones absolutas se iba a mostrar Delfino, para quien una hipótesis reconducible a tal tipo de omisiones, en realidad, estaría desprovista de relieve práctico, siendo casi imposible encontrar en la experiencia jurídica el caso de relaciones previstas a nivel de la normativa constitucional y, sin embargo, absolutamente desconocidas ni tan siquiera de modo indirecto por el legislador ordinario. ${ }^{47} \mathrm{Y}$ en fin, sin ánimo exhaustivo, Picardi, aún admitiendo que la diferenciación de Wessel tenía el mérito de poner de relieve la exigencia de una delimitación de las atribuciones de la Corte costituzionale en sus confrontaciones con el poder legislativo, consideraba que tal tipología se revelaba imprecisa y difícilmente utilizable en la práctica, ${ }^{48}$ y ello, en buena medida, porque tras ella subyacía un punto de vista político o sociológico antes que jurídico. ${ }^{49}$

III. Al margen ya de la polémica doctrinal, tiene particular interés aludir a si la finalidad pretendida por Wessel al formular su clasificación, que, como ya se ha dicho, no era otra que identificar el tipo de omisiones fiscalizables en sede constitucional, se iba a ver confirmada por la praxis de la jurisprudencia constitucional. Desde luego, algunos autores han considerado que en aquellos sistemas de justicia constitucional en que no existe el instrumento procesal específico de la acción de inconstitucionalidad por omisión, la fiscalización de las omisiones legislativas llevada a cabo por los Tribunales Constitucionales se ha limitado a las omisiones relativas, quedando las omisiones absolutas sujetas a fiscalización tan sólo allí donde, como en Portugal, Brasil o Hungría, existe un instrumento procesal específico de control de la inconstitucionalidad por omisión. La realidad nos muestra, sin embargo, que ello no es así. Nos referiremos a algunos puntuales ejemplos.

En Alemania, como ya expusimos, los años 1957 y 1958 van a marcar en la jurisprudencia del $B$ VerfG un punto de inflexión en torno a esta cuestión. En sus decisiones de 20 de febrero de 1957 y 11 de junio de 1958, dictadas ambas en sendos recursos de queja constitucional, el Tribunal admitía de modo inequívoco que la inconstitucionalidad podía producirse no sólo por acción, sino también por omisión legislativa.

\footnotetext{
46 Mortati, Costantino (1972), p. 928.

47 Delfino, Felice (1974). "Omissioni legislative e Corte costituzionale (delle sentenze costituzionali c. d. creative)", en Studi in onore di Giuseppe Chiarelli, Giuffrè, Milano, tomo secondo, pp. 911 y ss.; en concreto, p. 917.

48 PiCARDI, Nicola (1977). "Le sentenze "integrative» della Corte costituzionale", en Aspetti e tendenze del Diritto Costituzionale. Scritti in onore di Costantino Mortati, Giuffrè, Milano, vol. $4^{\circ}$, pp. 597 y ss.; en concreto, p. 606.

49 PICARDI, Nicola (1977), p. 604.
} 
Ciertamente, se trataba en ambos casos de supuestos de omisión parcial, dándose los primeros pasos para el reconocimiento dogmático por el $B V e r f G$ de la "exclusión arbitraria de beneficio" ("Willkürlicher gleichheitswidriger Begünstigungsausschluss”) vulneradora del principio de igualdad. El control de las inacciones del legislador no iba, sin embargo, a quedar circunscrito a este tipo de omisiones. En la importante Sentencia de 29 de enero de 1969, dando un paso adelante, el Tribunal Constitucional Federal llevaba a cabo la fiscalización de una omisión absoluta del legislador. Vale la pena detenerse mínimamente en tan trascendental caso.

El BVerfG iba a estimar a través de la mencionada decisión un Verfassungsbeschwerde interpuesto frente a una sentencia del Tribunal regional de Kiel, que priorizó la aplicación de varias disposiciones preconstitucionales del Código Civil aun cuando de ellas se derivaba una vulneración del principio de igualdad de los hijos habidos fuera del matrimonio ("den unehelichen Kindern) respecto de los hijos matrimoniales ("den ehelichen Kindern”), expresamente contemplado por el ya mencionado art. $6^{\circ} .5$ $G G$, en ese momento aún pendiente de desarrollo legislativo. El BVerfG, a la vista de la demora del legislador, entendió que no era exagerado suponer que se había llegado a la fecha del "plazo adecuado o razonable" si el legislador, veinte años después de entrada en vigor la Ley Fundamental, todavía no se había pronunciado sobre las normas de una parte fundamental de la vida como son las que contempla el art. $6^{\circ} .5 \mathrm{GG}$, pese a haber aprobado en el mismo período de tiempo numerosas leyes que, desde el punto de vista constitucional, eran mucho menos significativas y urgentes. Adicionalmente, el Tribunal iba a entender, que una vez transcurrido el "plazo razonable" asegurado al Parlamento para el cumplimiento del deber constitucional de legislar, al tratarse de una norma constitucional bastante precisa, los jueces y tribunales ordinarios podían (más bien debían) aplicar la norma constitucional directamente.

En definitiva, el Tribunal alemán no sólo ha controlado las omisiones relativas, sino que también lo ha hecho respecto de las absolutas en supuestos como el de referencia, en que la inacción del legislador ha propiciado la aplicación de normas preconstitucionales contrarias a valores y derechos fundamentales.

Algo análogo puede decirse de la doctrina establecida por la Corte costituzionale italiana. En su Sentencia $n^{\circ} 190$, de 1970, la Corte declaraba inconstitucional el art. 304 bis del Código de procedimiento penal, no por lo que decía, sino por lo que omitía; en concreto, lo tildaba de constitucionalmente ilegítimo en la parte en que excluía el derecho del defensor a asistir al interrogatorio de su defendido. Frente al rechazo radical de tal decisión por los órganos judiciales ordinarios, contrarios a aplicarla al entender que, al anular una omisión legislativa, la Corte costituzionale tendía a completar el Derecho objetivo, lo que excedía del ámbito de sus funciones, en su Sentencia $\mathrm{n}^{\circ}$ 62, de 1971, que Amato tildó de insólita, ${ }^{50}$ el juez constitucional italiano se hacía eco del problema que nos ocupa. Refiriéndose a la "sindacabilità delle omis-

50 Amato, Giuliano. (1971). “Troppo coraggio o troppa cautela nella Corte contestata?”, en Giurisprudenza Costituzionale, anno XVI, fasc. 2, pp. 603 y ss.; en concreto, p. 603. 
sioni del legislatore che si resolvono in violazione di precetti costituzionali", la Corte precisaba; "sindacabilità che non si può in assoluto escludere senza far venir meno in amplia misura le garanzie del sistema” ${ }^{51}$ Ciertamente, el caso citado puede considerarse reconducible a la categoría de las omisiones relativas, pues de resultas de la imprevisión del legislador se producía un trato discriminatorio, dado que mientras el Ministerio público estaba presente en el interrogatorio, a la otra parte, la defensa, le quedaba vedada la presencia, generándose además una violación del principio de igualdad de armas procesales. En cualquier caso, la Corte italiana ha tenido oportunidad de fiscalizar también omisiones absolutas del legislador.

También en España el Tribunal Constitucional ha llevado a cabo en ocasiones un control de las omisiones absolutas del legislador a través del instituto procesal del recurso de amparo. Paradigmática es al respecto la STC 31/1994, de 31 de enero de 1994, en la que el Tribunal conocía de dos recursos de amparo acumulados presentados contra sendas resoluciones administrativas del Gobierno Civil de Huesca por las que se había requerido a las entidades demandantes de amparo que cesaran en las emisiones de televisión por cable de ámbito local, desmontando sus instalaciones, en cuanto que tales actividades no podían considerarse lícitas al no existir una ley que las regulara, resoluciones administrativas que fueron corroboradas por sendas sentencias de la Sala de lo Contencioso-Administrativo del Tribunal Superior de Justicia de Aragón y de la Sala Tercera del Tribunal Supremo.

En su sentencia, el Tribunal Constitucional reconocía a los recurrentes su derecho a la libertad de expresión y de comunicación, constitucionalmente garantizado por los apartados a) y d) del art. 20.1 de la Constitución, anulando tanto las resoluciones administrativas como las sentencias confirmatorias. El juez constitucional razonaba como sigue: “...lo que no puede el legislador es diferir sine die, más allá de todo tiempo razonable y sin que existan razones que justifiquen la demora, la regulación de una actividad, como es en este caso la gestión indirecta de la televisión local por cable, que afecta directamente al ejercicio de un derecho fundamental como son los reconocidos en el art. 20.1 a) y d) CE, pues la ausencia de regulación legal comporta, de hecho, como ha ocurrido en los supuestos que han dado lugar a los presentes recursos de amparo, no una regulación limitativa del derecho fundamental, sino la prohibición lisa y llana de aquella actividad que es ejercicio de la libertad de comunicación (...) en su manifestación de emisiones televisivas de carácter local y por cable". ${ }^{52}$

No muy distinta había sido la doctrina sentada por el juez constitucional en una sentencia dos años y medio anterior, la STC 216/1991, pues en ella también abordaba una omisión absoluta, aun cuando a dicha omisión se anudaba la vigencia de una norma preconstitucional que generaba un trato discriminatorio, lo que creemos que emparentaba esta sentencia con la decisión del BVerfG de 29 de enero de 1969.

\footnotetext{
51 Sentencia de 30 de marzo de $1971, \mathrm{n}^{\circ}$ 62, terzo considerando in diritto. La sentencia puede verse en Giurisprudenza Costituzionale, anno XVI, 1971, fasc. 2, pp. 601 y ss.

52 STC 31/1994, de 31 de enero de 1994, fund. jur. $7^{\circ}$.
} 
En el caso en cuestión, el Tribunal Constitucional español otorgaba el amparo requerido a una demandante a la que le había sido rechazada por un acto administrativo su solicitud de acceso a las pruebas de ingreso en la función pública militar, con base en que no era posible admitir la petición hasta que fuere promulgada una ley que posibilitare el acceso de la mujer a las Fuerzas Armadas, acto administrativo que sería a su vez confirmado por una sentencia de la Sala Quinta del Tribunal Supremo. El juez constitucional otorgará el amparo y anulará tanto el acto administrativo como la sentencia del Tribunal Supremo, razonando al efecto que la incidencia del mandato contenido en el art. $9^{\circ} .2 \mathrm{CE}$ (que reproduce la famosa "cláusula Lelio Basso" de la Constitución italiana) sobre el que encierra el art. 14 (principio de igualdad formal e interdicción de discriminación, entre otras causas, por razón de sexo), supone una modulación de este último, que, entre otras consecuencias, y en lo que ahora importa, se traduce en que "exige de los poderes públicos, enfrentados a una situación de desigualdad de origen histórico, la adopción de una actitud positiva y diligente tendente a su corrección; de tal modo que, si bien no cabe, por lo general, mesurar ex constitutione la falta de celo y presteza del legislador en la procura de aquella corrección cuando una desigualdad de hecho no se traduce en una desigualdad jurídica, la concurrencia de esta última por la pervivencia en el ordenamiento de una discriminación no rectificada en un lapso de tiempo razonable habrá de llevar a la calificación de inconstitucionales de los actos que la mantengan. ${ }^{53}$

En resumen, los distintos casos expuestos nos muestran cómo los Tribunales Constitucionales de esos tres países, no obstante no existir en ellos específicos institutos de control de la inconstitucionalidad de una omisión, han fiscalizado a través de cauces procesales diferentes las omisiones relativas, pero también las absolutas, del legislador. Parece claro, pues, que la praxis jurisprudencial no ha corroborado la finalidad última a que respondió en su momento la tipología creada por Wessel.

\section{CARACTERIZACIÓN JURÍDICA DE LA OMISIÓN CONSTITUCIONALMENTE RELEVANTE}

I. El intento de conceptualizar lo que se entiende por omisión inconstitucional del legislador presupone, con carácter previo, identificar cuál ha de ser el objeto del control a realizar en sede constitucional, y es en relación a esta cuestión donde se visualiza una frontal divergencia doctrinal entre las tesis que se conocen comúnmente como obligacionales y normativistas.

Para quienes se sitúan en la primera de las posiciones, la fiscalización constitucional se proyecta sobre el incumplimiento por el legislador de una determinada obligación de legislar que le impone la Constitución, visión que, como parece lógico, sitúa en primer plano la cuestión del período de tiempo de inacción del legislador. Asî, para

53 STC 216/1991, de 14 de noviembre de 1991 , fund. jur. $5^{\circ}$, in fine. 
Miranda, ${ }^{54}$ por omisión se entiende la falta de medidas legislativas necesarias, proviniendo el efecto violatorio de la Constitución unas veces de la completa inercia del legislador y otras, de su deficiente actividad. También Canotilho cree que hay una omisión legislativa inconstitucional cuando el legislador no adopta las medidas legislativas necesarias para dar ejecución a los preceptos constitucionales que, de forma permanente y concreta, le imponen tal acción. ${ }^{55}$ Estas concepciones, a nuestro juicio, son deudoras de las propias normas constitucionales portuguesas, en las que, al igual que en las de la Constitución brasileña de 1988, la inacción a lo largo de un determinado período de tiempo adquiere una indiscutible relevancia a la hora de dilucidar si la quiescencia del legislador es o no inconstitucional.

Los que se ubican en la posición normativista ponen el acento no tanto en la omisión propiamente dicha, visualizada como incumplimiento de una obligación de legislar, cuanto en las consecuencias de la misma, subrayando que el objeto del control habrá de ser la norma implícita que la inacción legislativa propicia.

Ha sido la doctrina italiana la que mayormente se ha alineado en esta dirección. Giuseppe Branca, a la sazón presidente de la Corte costituzionale cuando ésta se pronunció a través de la trascendental sentencia $n^{\circ} 62$, de 1971 , iba a contribuir a la consolidación dogmática del control de las omisiones del legislador. En una comunicación presentada ante la prestigiosísima Accademia dei Lincei de Roma, en 1972, formulaba unas reflexiones que, en lo que ahora importa, nos parecen del mayor interés: ${ }^{56}$ " $E$ possibile annullare una legge (o una sua parte) non scritta? -se interrogaba Branca- La Corte ha risposto di sì", y ello porque superando la objeción ("che è -apostilla Brancaquanto di più formalistico si possa immaginare") según la cual, "la Corte può pronunciarsi su disposizioni scritte, soltanto su di esse", ha replicado que, en general, "la disposizione scritta, tacendo, nega, non consente, e perciò contiene anche la norma non scritta; considerando la norma come precetto, se essa consente qualcosa (solo) ad alcuni, segno è che non permette ad altri e quando impedisce ad uno permette ad altri: dalla stessa natura precettiva discende che, toccata dal legislatore una materia, questa risulta tutta presa dal comando legislativo, rientra per intero nella disciplina della legge".

Pocos años después, Crisafulli se pronunciaba en similar dirección al sostener que, declarando inconstitucional una omisión legislativa, la sentencia de la Corte no hacía más que extender una norma vigente, removiendo un obstáculo (lo que podríamos tildar de norma negativa) frente a su aplicabilidad a determinadas categorías excluidas. ${ }^{57}$ Es evidente que el razonamiento de Crisafulli estaba pensado en función de una

54 Miranda, Jorge (1977). "Inconstitucionalidade por omissâo”, en la obra coloectiva, Estudos sobre a Constituiçâo, vol. I, Livraria Petrony, Lisboa, 1977, pp. 333 y ss.; en concreto, p. 345.

55 Gomes Canotilho, J.J. (2002). Direito Constitucional e Teoría da Constituiçâo (Coimbra, Almedina), p. 1022.

56 Giuseppe Branca (1972). "Caratteristiche e funzione dei giudizi di legittimità costituzionale” (Relazione dell'Accademia dei Lincei, 1972). Seguimos la transcripción que hace Giustino D'Orazıo: "Le sentenze costituzionali additive tra esaltazione e contestazione”, en Rivista trimestrale di Diritto pubblico, fasc. 1, pp. 61 y ss.; en concreto, p. 72.

57 CRISAfull, Vezio (1984). "La Corte costituzionale ha vent'anni”, en La Corte costituzionale tra norma 
omisión relativa, mientras que el de Branca presentaba una mayor amplitud de miras. En fin, Modugno, en una posición semejante, aducía ${ }^{58}$ que de una disposición bien puede obtenerse una norma negativa, sea en el sentido de una norma que establece una prohibición, sea en aquel otro de una norma que deja indefinida una situación o un comportamiento, hallándose la Corte perfectamente legitimada para golpear ("colpire") tal norma negativa en cuanto se manifieste inconstitucional.

La posición que acaba de exponerse contrasta con la del BVerfG, cuyo presidente, Wolfgang Zeidler, en la ponencia presentada en Lisboa, con ocasión de la $7^{\text {a }}$ Conferencia de Tribunales Constitucionales Europeos (1987), refiriéndose a esta cuestión y haciéndose eco de la crítica de unos demandantes, en el sentido de que en una ley de la que conocía el Tribunal había un vacío contrario a la Constitución, precisaba: "mais selon le droit dogmatique il était difficile de déclarer nul un vide juridique" ${ }^{59}$

II. No es fácil esbozar una dogmática con pretensiones obviamente de generalidad acerca del instituto que nos ocupa, lo que se comprende bien a la vista de los peculiares rasgos de cada sistema de justicia constitucional y de las diversas técnicas de fiscalización utilizadas. No es casual que entre la doctrina portuguesa y brasileña, y también en la jurisprudencia del Tribunal Constitucional portugués y en la del Supremo Tribunal Federal brasileño se imponga la concepción obligacional, pues las respectivas Constituciones, al contemplar el instituto de la acción directa de inconstitucionalidad por omisión, sientan las bases conducentes a ello. Por contra, el hecho de que el control de las omisiones del legislador llevado a cabo en Alemania, Italia y España, por poner tres ejemplos concretos, se haya verificado con ocasión de la aplicación de las leyes, aunque más bien habría que decir que con ocasión de la aplicación de normas implícitas que han entrado en juego de resultas de la inexistencia de una norma legislativa expresamente requerida por la Constitución, o también de textos legales preconstitucionales cuya aplicación se produce como consecuencia de la falta de desarrollo legislativo de los mandatos constitucionales, contribuye a explicar que en estos países, o por lo menos en Italia, de modo muy particular, y España, no así en Alemania, haya arraigado la visión normativista. De ahí la inexcusable necesidad de ser cauteloso a la hora de pretender establecer un concepto de omisión legislativa inconstitucional con pretensiones de generalidad.

Por nuestra parte, creemos con Pereira da Silva ${ }^{60}$ que la omisión inconstitucional se nos presenta como una realidad bifronte, esto es, si por un lado, tal omisión es el

giuridica e realtà sociale (Bilancio di vent'anni di attività), a cura di Nicola OcchIOcuPo, CEDAM, Padova, 1984 (ristampa), pp. 69 y ss.; en concreto, p. 84. Este artículo fue inicialmente publicado en Giurisprudenza Costituzionale, anno XXI, 1976, fasc. 10, pp. 1694 y ss.

58 Modugno, Franco. (1985). "La Corte costituzionale oggi”, en Scritti su la Giustizia Costituzionale. In onore di Vezio Crisafulli, CEDAM, Padova, 1985, vol. I, pp. 527 y ss.; en concreto, nota 62, en pp. 564-565.

59 ZEIDLER , Wolfgang. (1987), "Cour constitutionnelle allemande" (7ème Conférence des Cours constitutionnelles européennes), en Annuaire International de Justice Constitutionnelle, III, 1987, pp. 37 y ss.; en concreto, p. 48.

60 Pereira da Silva, Jorge. (2003). Dever de legislar e protecçâo jurisdicional contra omissôes legislativas (Contributo para uma Teoria da Inconstitucionalidade por Omissâo), Universidade Católica Editora, Lisboa, p. 13. 
incumplimiento de una obligación constitucional del legislador, por otro, es también el resultado objetivamente producido en el ordenamiento jurídico por ese mismo incumplimiento. Dicho de otro modo, la caracterización jurídica del concepto que nos ocupa ha de atender tanto a la perspectiva obligacional como a la óptica normativa. Y desde esta óptica, las concepciones obligacionales y normativistas se manifiestan reductoras frente a la complejidad de la figura jurídica considerada.

La conclusión es, a nuestro modo de ver, bastante clara: la inconstitucionalidad de una omisión exige constatar que el legislador ha incumplido la obligación que la Constitución le exige de dictar un texto legislativo con el que dar adecuada respuesta a un mandato constitucional o con el que posibilitar la plena eficacia de una determinada previsión constitucional, incumplimiento que se ha prolongado en el tiempo más allá de un "plazo razonable", pero también exige verificar de igual modo que la ausencia de esa normación "constitucionalmente debida" ha propiciado la vigencia de normas preconstitucionales en contradicción con los mandatos constitucionales, o que se ha producido una situación en las relaciones jurídico-sociales inequívocamente opuesta a las previsiones de la Constitución. Desde otra óptica, la verificación de la inconstitucionalidad de una inacción del legislador, tratándose ésta de una omisión parcial o relativa, requiere verificar que el poder legislativo, al dictar el texto, ha incurrido en una omisión parcial vulneradora del principio de igualdad, al generar, por ejemplo, una exclusión arbitraria de beneficio.

Como puede apreciarse por lo que se acaba de decir, no siempre podrá reconducirse el control de las omisiones a la existencia de una norma implícita. Piénsese en ciertos derechos prestacionales o socio-laborales cuya falta de desarrollo conduce a privarlos de toda eficacia. La omisión puede no propiciar aquí la vigencia de una norma implícita o preconstitucional, sino simplemente el vacío jurídico, un vacío en contradicción con un mandato constitucional. Por poner un ejemplo, la falta de desarrollo por el legislativo de la previsión del art. 37.VIII de la Constitución brasileña ("A lei reservará percentual dos cargos e empregos públicos para as pessoas portadoras de deficiência e definirá os critérios de su admissâo"), lisa y llanamente, se traducirá en un vacío jurídico que, prolongado en el tiempo más allá de un plazo razonable, generará una situación social frontalmente contradictoria con las previsiones constitucionales. En supuestos análogos a éste, es claro que el objeto del control no será una norma, sino la determinación de si la omisión es constitucionalmente reprobable, tanto por venir obligado el legislador a dictar un texto legislativo y no haberlo hecho no obstante haberse superado un "plazo razonable", como por la constatación de que a esa omisión se ha anudado una situación en las relaciones jurídico-sociales flagrantemente contradictoria con la Norma suprema.

III. A partir de la concepción que acabamos de exponer, se pueden delimitar con facilidad una serie de presupuestos configuradores de la omisión inconstitucional. A ellos pasamos a referirnos.

A) El primero de esos presupuestos es el incumplimiento de un deber constitucional de legislar. La omisión legislativa como concepto jurídicamente relevante no es un 
simple no hacer, ni se puede confundir con la mera inercia del órgano legislativo. Como escribe Canotilho, ${ }^{61}$ "un entendimento naturalístico-formal de omissâo -a omissâo como simples nâo actuar- nâo pode aceitar-se: nâo possibilita a definiçâo de uma omissâo legislativa constitucionalmente relevante, dado que esta só pode entenderse como nâo cumprimento de imposiçôes constitucionais concretas”.

No basta, pues, la inacción; es preciso que la pasividad del legislador entrañe la inobservancia de un deber constitucional de legislar. Como afirma Pestalozza, ${ }^{62}$ "das Unterlassen des Gesetzgebers ist verfassungswidrig, wenn die Verfassung ein HandeIn des Gesetezgebers fordet" (la omisión del legislador es inconstitucional cuando la Constitución le exige una actuación).

No vamos a volver a hacernos eco de las diferenciaciones que la doctrina ha establecido entre diferentes tipos de mandatos, pues ya nos ocupamos de ello. Recordemos no obstante que la posibilidad de que los tribunales ordinarios puedan, a través del proceso de la Konkretisierung, dar eficacia a la norma constitucional necesitada de desarrollo, en defecto de la actuación del legislador, no cierra la posibilidad de que sea declarada en sede constitucional la inconstitucionalidad de la inacción legislativa cuando, transcurrido un período de tiempo razonable, no hayan sido dictadas las medidas legislativas necesarias. Ciertamente, la sustitución ("Stellvertretung") del legislador por los tribunales impedirá en un primer momento la declaración de la inconstitucionalidad, pero tras el decurso de un plazo razonable tal impedimento desaparecerá. Innecesario es que precisemos que no nos estamos refiriendo a normas autoaplicativas, pues es claro que en tal caso no cabrá en modo alguno declarar la inconstitucionalidad de la omisión.

B) El segundo presupuesto es el transcurso de un período de tiempo razonable. En referencia a Portugal, Miranda ha escrito ${ }^{63}$ que el juicio de inconstitucionalidad por omisión se traduce en un juicio sobre el tiempo en que debería ser elaborada la norma, por lo que ninguna omisión puede ser descrita en abstracto, sino tan sólo en concreto, determinada por hechos de signo positivo. La ausencia o insuficiencia de la norma legal no puede ser deslindada de un determinado tiempo histórico, señalado por la necesidad de producción legislativa y cuya duración, mayor o menor, será prefijada -muy raramente- por la propia Constitución o dependerá de la naturaleza de las cosas (o sea, de la naturaleza de la norma constitucional no exigible por sí misma en confrontación con las situaciones de hecho). Esta doctrina ha sido plenamente asumida por el Tribunal Constitucional portugués (con anterioridad a 1982, por la Comisión Constitucional), pudiendo afirmarse otro tanto del Supremo Tribunal Federal brasileño.

Podría pensarse que este entendimiento es válido tan sólo para aquellos países que, como Portugal o Brasil, han configurado constitucionalmente el instituto procesal

61 Gomes Canotilho. J.J. (1982), p. 334.

62 Pestalozza, Christian: “Noch Verfassungsmässige» und "bloss Verfassungswidrige» Rechtslagen”, op. cit., p. 526.

63 Miranda, Jorge. (1977). “La Justicia Constitucional en Portugal”, en Anuario Iberoamericano de Justicia Constitucional, 1977, pp. 325 y ss.; en concreto, pp. 345-346. 
de la acción directa de inconstitucionalidad por omisión. No nos parece, sin embargo, que sea asî, y la jurisprudencia constitucional sentada en otros países creemos que lo avala. Paradigmática es al efecto la sentencia del BVerfG de 29 de enero de 1969, de la que ya nos hemos hecho eco con algún detenimiento. Recordemos que el Tribunal Constitucional Federal entenderá que la voluntad de la Constitución no puede ser interpretada en el sentido de que el legislador pueda dilatar el encargo encomendado por el constituyente por tiempo indeterminado, con la consecuencia de que la situación legal, rechazada y considerada por el constituyente necesitada de una urgente reforma, pueda quedar en vigor por tiempo indeterminado tras la entrada en vigor de la Constitución. Dicho de otro modo, aunque la Constitución no delimite un plazo para la intervención del legislador, éste no puede demorar indefinidamente el cumplimiento de su deber de legislar. En definitiva, es meridianamente claro que el BVerfG maneja, aunque no la califique expresamente así (el BVerfG habla de un "plazo adecuado"), la doctrina del "plazo razonable" de que dispone el legislador para dar cumplimiento a los mandatos que le imponen ciertas normas constitucionales.

También el Tribunal Constitucional español ha hecho suyo este elemento en algunas sentencias, como sería el caso de la ya comentada STC 31/1994, en la que el juez constitucional razona, como ya dijimos, que "lo que no puede el legislador es diferir sine die, más allá de un plazo razonable y sin que existan razones que justifiquen la demora, la regulación de una actividad (...) que afecta directamente el ejercicio de un derecho fundamental". ${ }^{64}$

Añadamos que, a nuestro entender, aun cuando consideremos que el objeto del control llevado a cabo en sede constitucional pueda ser la norma preconstitucional cuya aplicación es posibilitada por la falta de desarrollo constitucional, o la norma implícita que cobra vida de resultas de una norma legislativa parcial o el acomodo a la Constitución de la situación jurídico-social que ha generado la inacción legislativa y, en íntima conexión con ella, la bondad constitucional de esa misma inacción, nada de ello puede conducir a privar de toda relevancia jurídica, en orden a la fiscalización de la omisión, al elemento temporal al que venimos aludiendo.

C) El tercer presupuesto es el efecto objetivo de violación de la Constitución. La omisión legislativa, aun siendo un comportamiento pasivo, está lejos de ser neutro en sus consecuencias, propiciando efectos de dispar naturaleza que tienen como común denominador la violación objetiva de la Norma suprema. No nos hallamos ante una omisión inocua desde el punto de vista jurídico, sino que al generar la aplicación de normas implícitas en contradicción con la Constitución o la pervivencia en las relaciones jurídico-sociales de situaciones en franco contraste con los postulados constitucionales, se traduce en frontales vulneraciones de la lex superior, circunstancia que ha conducido a Miranda a escribir que, al límite, la inconstitucionalidad por omisión se reconduce a una inconstitucionalidad por acción. ${ }^{65}$

64 STC 31/1994, de 31 de enero, fund. jur. $7^{\circ}$.

65 Miranda, Jorge (1977), p. 346. 
La doctrina ha puesto el acento particularmente en la lesión de derechos que puede desencadenar la ausencia de norma legislativa. Y ciertamente así es. Unas veces la lesión se conecta con la dimensión prestacional de un derecho (piénsese, por ejemplo, en el derecho a la participación en los beneficios o resultados de las empresas que la Constitución brasileña de 1988 garantiza en su art. $7^{\circ}$.XI, remitiéndose al efecto a lo que disponga la ley), mientras que en otras ocasiones son los llamados intereses difusos los que pueden verse conculcados de resultas de la inacción (pensemos en el art. 60.3 de la Constitución portuguesa, que reconoce a las asociaciones de consumidores y a las cooperativas de consumo el derecho, en los términos de una ley, al apoyo del Estado y a ser oídas sobre las cuestiones que manifiesten respecto a los derechos de los consumidores). Pero al margen de los anteriores, otros muchos derechos pueden verse lesionados (recuérdense las libertades de expresión y de comunicación vulneradas en España de resultas de la ausencia de una ley sobre la televisión local por cable).

Es este efecto lesivo de derechos dimanante de la inactividad del legislador el argumento que conduce a algunos autores a considerar que resulta difícil imaginar un control abstracto de la omisión legislativa, desconectado por ello mismo de los problemas de aplicación e interpretación de la regla jurídica a los casos particulares. ${ }^{66} \mathrm{En}$ similar dirección, se sostiene que para el control de los silencios del legislador son necesarios actos de aplicación en los que se manifieste el contenido normativo efectivo de ese silencio, que no sería otro que la norma implícita contradictoria con los postulados constitucionales. ${ }^{67}$

Nos parece claro que la expresión natural del control de las omisiones legislativas se manifiesta en los casos concretos, pero de ahí no creemos que deba desprenderse la inconveniencia o imposibilidad de un control de tales omisiones en abstracto. Bastaría al efecto con pensar en la ineficacia de los derechos prestacionales que puede anudarse a su falta de desarrollo legislativo, pudiendo servir de ejemplo paradigmático el antes mencionado derecho a la "la participaçâo nos lucros, ou resultados, desvinculada da remuneraçâo" del art. $7^{\circ}$.XI de la Constitución brasileña de 1988. Piénsese, adicionalmente, en que si el legislador brasileño omite más allá de un plazo razonable dictar la ley que le exige el art. 37.VIII de la Carta de 1988, en la que debe contemplar el porcentaje de cargos y empleos públicos que se ha de reservar a las personas deficientes, definiendo a la par los criterios para su admisión, independientemente de que se suscite o no un caso litigioso, se estará generando una situación en el marco jurídico regulador del acceso a la función pública claramente lesiva de un derecho constitucional reconocido a las personas con minusvalías o deficiencias. Los ejemplos podrían multiplicarse, y no sólo, desde luego, en relación a previsiones de la Constitución brasileña. En supuestos de esta naturaleza, es perfectamente comprensible que quien esté legitimado para instar el control de las omisiones, desencadene tal proceso de fiscalización.

66 Así, Ahumada Ruiz, $M^{a}$ Ángeles (1991). "El control de constitucionalidad de las omisiones legislativas", en Revista del Centro de Estudios Constitucionales, $n^{\circ}$ 8, Enero/Abril, pp. 169 y ss.; en concreto, p. 173.

67 VillaVerde MenÉndez, Ignacio (1997). La inconstitucionalidad por omisión, (Madrid, McGraw-Hill), p. 49. 
En definitiva, presupuesto nuclear de la omisión inconstitucional es una lesión objetiva de las previsiones constitucionales. Sin transgresión de las normas constitucionales no hay inconstitucionalidad ni por acción ni por omisión. No es, por tanto, el silencio del legislador lo que por sí solo vulnera la Constitución, sino la interacción de la omisión de un deber constitucional de legislar prolongada en el tiempo más allá de un plazo razonable con su consecuencia objetivamente transgresora de la Norma suprema. La inconstitucionalidad aparece, pues, como la resultante de diferentes presupuestos estrechamente interconectados.

D) La intencionalidad de la inactividad del legislador, lejos de poder considerarse un presupuesto de la omisión inconstitucional, es por entero intrascendente a los efectos que nos ocupan. En su excelente trabajo sobre las omisiones legislativas, Mortati iba a tratar de diferenciar las omisiones de las lagunas, ${ }^{68}$ a cuyo efecto recurría a una triple consideración: las omisiones son, ante todo, incumplimiento de una obligación de hacer, mientras que parece claro que no puede admitirse que el legislador venga obligado a regular todos aquellos supuestos que puedan ser objeto de una normación, en ausencia de la cual se producirá la laguna; en segundo término, para Mortati, las omisiones son siempre el resultado de un acto voluntario ("di un atto di volontà”), mientras que las lagunas pueden producirse de modo involuntario; finalmente, mientras la sentencia con la que se trata de colmar la laguna cumple la función de dar complitud al ordenamiento jurídico, la que declara la inconstitucionalidad de una omisión puede ser a su vez fuente de otras lagunas.

La posición de Mortati es clara, aunque discutible. Para el gran iuspublicista italiano, la omisión es siempre fruto de un acto voluntario, de una clara decisión de no hacer por parte del legislador. Por lo mismo, tras la omisión subyacería una voluntad política en favor de la inacción; esa intencionalidad convertiría al legislador en culpable de la omisión, que podría incluso llegar a tildarse de dolosa.

Tal visión no deja de suscitar delicados problemas. Admitiendo a priori una violación constitucional dimanante de la omisión, ¿por qué introducir el elemento intencional para las violaciones de la Constitución por omisión, cuando ese elemento es por entero intrascendente en las transgresiones constitucionales por acción? ¿Cómo delimitar el tiempo en el que la omisión es fruto de la libre capacidad configuradora del legislador, de aquel otro momento temporal en el que la omisión pasa a ser el resultado de una actuación dolosa del legislador? Es cierto que, precedentemente, nos hemos referido al elemento del "plazo razonable", pero en ningún momento lo hemos hecho para enjuiciar la conducta del legislador, para tratar de apreciar si su actitud es o no dolosa, sino tan sólo para ponderar si la situación contraria a la Constitución generada por la inacción puede tildarse de inconstitucional, al haber transcurrido ya, a juicio del órgano fiscalizador, ese período de tiempo razonable cuyo agotamiento convierte una norma jurídica o una situación en el marco de las relaciones jurídico-sociales, dimanantes de una omisión legislativa en contradicción con la Constitución en inequívocamente inconstitucional.

68 Costantino MORTATI (1972), p. 927, nota 4. 
Quizá Mortati recurra al elemento de la voluntad, de la intencionalidad, con que va a caracterizar la omisión legislativa, para propiciar así su control, por cuanto de esta forma parece nítidamente separada de la simple laguna jurídica que, en principio, Mortati considera irrelevante, pues al legislador no puede imponerse una obligación universal de regular todas las situaciones posibles en la vida social. Pero con ello plantea dos problemas adicionales de mucha mayor complejidad y aún diríamos que gravedad.

El primero de esos problemas es que deja en manos del órgano fiscalizador la dificultosa tarea de llevar a cabo el control de la intencionalidad del legislador inactivo, un proceso de control, como dice Ahumada, ${ }^{69}$ de la "mens legislatoris", con lo que ello entraña de transmutar el control supuestamente aséptico de si la norma implícita, la norma que ha de aplicarse en defecto de aquella otra omisa o la situación jurídicosocial desencadenada por la inacción, son conformes con los postulados constitucionales, en un control de intenciones, por entero subjetivo, que poco o nada tiene que ver con el control de constitucionalidad.

Y el segundo, y no menor, problema es que el planteamiento de Mortati convierte el control de las omisiones legislativas en una fiscalización directamente orientada hacia la libre capacidad de configuración de que goza el legislador. Dicho de otro modo, la tesis del iuspublicista italiano acentúa hasta extremos inadmisibles la idea de que el control omisivo es un control básicamente político en el que lo que se fiscaliza no es la situación constitucionalmente lesiva a que ha conducido el silencio del legislador, sino la decisión política del poder legislativo de no legislar. Es cierto, como dice Picardi, que el comportamiento omisivo del legislador se traduce inevitablemente en una elección política. "Anche l'inerzia -añade el propio autor ${ }^{70}$ è̀, in definitiva, un modo in cui si esplica la discrezionalità del legislatore”. Ahora bien, no es esa opción lo que interesa fiscalizar en sede constitucional, pues, considerada en abstracto, podría entenderse sustentada en la libertad de configuración de que el propio legislador goza.

En definitiva, creemos por entero irrelevante, a los efectos del instituto que nos ocupa, la intencionalidad del legislador. Que la inacción desencadene un vicio de inconstitucionalidad por omisión no depende de que la misma responda a una voluntad determinada del legislador, sino, lisa y llanamente, a que existiendo un deber constitucional de legislar, el mismo haya sido incumplido más allá de un plazo razonable, generándose de resultas de ello la vigencia de normas contrarias a la Constitución o un vacío jurídico igualmente disconforme con ella.

Es verdad, desde luego, que algún sector de la doctrina científica ha vinculado en algún país, como sería el caso de Brasil, la inconstitucionalidad al presupuesto de la intencionalidad del legislador. Y así, se ha hablado de que existe inercia relevante constitucionalmente cuando hay inactividad consciente en la aplicación de la Consti-

69 Ahumada Ruiz, $M^{a}$ Ángeles. "El control de constitucionalidad de las omisiones legislativas”, op. cit., p. 174.

70 PiCARDI, Nicola (1977), pp. 604-605. 
tución. ${ }^{71}$ Este planteamiento no nos parece suscribible, siendo deudor, a nuestro entender, de una situación de hecho históricamente arraigada: la displicente actitud de los legisladores de buen número de países latinoamericanos, Brasil de modo muy especial, hacia las normas relativas a los derechos y libertades constitucionales.

\section{TÉCNICAS CON LAS QUE HACER FRENTE A LAS OMISIONES LEGISLATIVAS}

I. Cuando se alude al control de las omisiones legislativas se tiende sistemáticamente a pensar en el control abstracto de las inacciones del legislador a través de un específico mecanismo procesal, control cuya consagración no sólo ha demorado en el constitucionalismo europeo de la segunda postguerra tres décadas, hasta su recepción por la Constitución portuguesa de 1976, sin que ello entrañe ignorar el precedente yugoslavo de 1974, sino que su institucionalización ha sido realmente episódica durante bastante tiempo y aún hoy podríamos hablar de una consagración minimalista del instituto procesal en cuestión. Sin embargo, una visión que al abordar este problema se circunscribiera a tal fiscalización no dejaría de ser incompleta y sesgada, al ignorar la realidad constitucional de otros países europeos, pues lo cierto es que la ausencia de instrumentos específicos de control de la inacción del legislador no ha impedido, ni mucho menos, que su fiscalización en sede constitucional sea una realidad en muy diferentes países, aun no hallándose dotados de tal instrumento procesal de control de la omisión.

Los Tribunales Constitucionales europeos, o al menos buen número de ellos, al hilo de los mecanismos de fiscalización de la inconstitucionalidad por acción o también por intermedio de los recursos de tutela de los derechos fundamentales, han creado de modo pretoriano una serie de técnicas decisorias más o menos originales a través de las cuales han posibilitado el control de las omisiones legislativas. No ha obstado a ello el hecho de que los recursos jurisdiccionales, en gran medida por la inercia de una tradición liberal todavía hoy bien presente en el Derecho procesal, sólo quepan frente a actos formales, con la obvia ignorancia subsecuente de las omisiones. De esta forma, yendo más allá de las estrictas previsiones constitucionales y aún legales, los órganos de la justicia constitucional, particularmente en Europa, se han enfrentado a los retos que planteaban las vulneraciones constitucionales resultantes no de actos lesivos, sino de omisiones a las que se anudaban análogos efectos transgresores de las normas constitucionales.

Las dificultades del empeño no eran pocas. Como señalara Trocker, ${ }^{72}$ refiriéndose a la justicia constitucional germano-federal, los mecanismos de control de constitucio-

71 Da Cunha Ferraz, Anna Cândida (2005). "Protecçâo jurisdicional da omissâo inconstitucional dos poderes locais”, em Revista Mestrado em Direito, ano 5, n 5, (Sâo Paulo, Osasco), 2005, pp. 157 y ss.; en concreto, p. 160.

72 TROCKer, Nicolò (1970). "Le omissioni del legislatore e la tutela giurisdizionale dei diritti di libertà (Studio comparativo sul diritto tedesco), en Archivio Giuridico "Filippo Serafini", volume CLXXVIII, Fascicoli 12, Gennaio/Aprile, 1970, pp. 88 y ss.; en concreto, pp. 106-107. 
nalidad de las leyes parecían estructurados de modo tal que no se comprendían aquellos casos en que el legislador hubiera violado no ya por acción, sino por omisión, la Grundgesetz. Ni el control normativo abstracto ("abstrakte Normenkontrolle”) ni el control normativo concreto ("konkrete Normenkontrolle") parecían tener por objeto un comportamiento omisivo del legislador. Ello no impediría que el BVerfG pudiera conocer de las omisiones del legislador, particularmente de las relativas, aunque, como ya se ha visto, también a veces de las absolutas, presentándose el recurso de queja constitucional (Verfassungsbeschwerde) como un instrumento idóneo para el desencadenamiento de este control en sede constitucional.

La canalización del control de constitucionalidad de las omisiones del legislador no iba, sin embargo, a quedar circunscrita tan sólo a aquellos recursos, como el Verfassungsbeschwerde, encaminados a la tutela de derechos constitucionales. El caso italiano ejemplifica muy bien esta circunstancia. El control concreto de constitucionalidad, llevado a cabo con ocasión de la aplicación de la ley, iba a convertirse en el país transalpino en un cauce especialmente útil a este respecto.

Posibilitada esta fiscalización en sede constitucional, la creatividad de algunos Tribunales Constitucionales iba a hacer el resto. Una pluralidad de técnicas decisorias tanto por parte del Bundesverfassungsgericht como de la Corte costituzionale, iban a propiciar el dar una respuesta jurídica adecuada a los retos que planteaba el control de las omisiones legislativas. Y de ellas nos ocupamos a renglón seguido, para, más adelante, pasar a referirnos a los instrumentos procesales específicos de control creados en Portugal y en otros países.

\section{A) La creación pretoriana de técnicas decisorias con las que controlar las omisiones del legislador}

I. El Bundesverfassungsgericht ejemplifica la creatividad jurisprudencial a que antes aludíamos, que contra lo que pudiera pensarse, y ya de algún modo se ha señalado, no se encamina en la dirección de invadir funciones legislativas, sino justamente en sentido contrario. La técnica de la declaración de inconstitucionalidad sin nulidad (Unvereinbarkeitserklärung) lo ejemplifica meridianamente. Y en tal sentido, entre los argumentos que Pestalozza menciona como justificación de la renuncia a la técnicamente posible ("technisch mögliche") declaración de nulidad en sede constitucional, se refiere al respeto a la libre configuración del legislador en el marco del art. $3^{\circ} .1 \mathrm{GG}$ ("die Rücksichtnahme auf die sog. "Gestaltungsfreiheit des Gesetzgebers" in Rahmen des Art. 3 I GG") a través de la declaración de incompatibilidad, ${ }^{73}$ esto es, de mera incompatibilidad o de inconstitucionalidad sin nulidad. Es ésta, por lo demás, una opinión ampliamente compartida por la doctrina germana, pero no sólo por ella, tam-

73 Pestalozza, Christian (1991). Verfassungsprozessrecht (Die Verfassungsgerichtsbarkeit des Bundesund der Länder), C.H. Beck'sche Verlagsbuchhandlung, 3, völlig neubearbeitete Auflage ( $3^{\mathrm{a}}$ ed. completamente revisada), München, p. 344. 
bién por la foránea. Así, Crisafulli sostiene ${ }^{74}$ que esta variante de decisión tiene la finalidad de dejar plenamente libre al poder legislativo en la elección de los modos con los que hacer cesar la comprobada vulneración de la Constitución. ${ }^{75}$ La libertad de configuración del legislador -se llega a escribir ${ }^{76}$ - ha pasado a ser casi una especie de cláusula general para justificar la aplicación de la declaración de inconstitucionalidad sin un pronunciamiento de nulidad, con base en que tal libertad exige que sea el poder legislativo quien decida acerca de las posibles alternativas en presencia para la eliminación de la inconstitucionalidad.

Quizá antes de aludir a las técnicas decisorias a las que el $B V e r f G$ ha recurrido para el control de las omisiones del legislador ${ }^{77}$ convenga recordar que el instrumento procesal utilizado para hacer frente a tales omisiones ha sido el recurso de queja constitucional (Verfassungsbeschwerde). Es cierto que, en un primer momento, el BVerfG no pareció mostrarse muy proclive a esta modalidad de control. En efecto, ya en la mencionada decisión de 19 de diciembre de 1951 el Tribunal hubo de enfrentarse con el problema de las omisiones supuestamente inconstitucionales, reconociendo en esa sentencia que de la sujeción a la Constitución, y muy particularmente a los Grundrechte, podían surgir para los órganos judiciales y administrativos concretas obligaciones de actuar, cuya inobservancia podía conducir a una auténtica omisión inconstitucional lesiva de derechos fundamentales. Sin embargo, en la misma decisión, el Tribunal, en línea de principio, excluyó que una inacción del legislador pudiera dar lugar a una omisión inconstitucional ${ }^{78}$ lesiva de derechos fundamentales. ${ }^{79}$ A la vista del fallo, Lechner pondría de relieve ${ }^{80}$ que el hecho de que el Tribunal no reconociera la posibilidad de una inconstitucionalidad por omisión del legislador, no entrañaba que el legislador no debiese extraer, en el ámbito de sus competencias y de sus facultades legislativas, las conclusiones necesarias de una sentencia como ésta. En cualquier caso, tal y como ya dijimos, en los años 1957 y 1958 el $B V e r f G$, en sendas decisiones de las que ya nos hicimos eco, abandonando sus primeros posicionamientos, admitiría de

74 Crisafulul, Vezio (1977), p. 141.

75 Análoga posición mantienen, entre otros, CERVATI, Angelo Antonio. (1989), "Incostituzionalità delle leggi ed efficacia delle sentenze delle Corti costituzionali austriaca, tedesca ed italiana”, en Quaderni Costituzionali, anno IX, $\mathrm{n}^{\circ}$ 2, Agosto 1989, pp. 257 y ss.; en concreto, p. 270. Asimismo, Jean-Claude BÉGuIN: Le contrôle de la constitutionnalité des lois en République Fédërale d'Allemagne, Economica, Paris, 1982, pp. 250 y ss.

76 Ferreira Mendes, Gilmar (2005). Jurisdiçâo Constitucional (O controle abstrato de normas no Brasil e na Alemanha), $5^{\text {a }}$ ediçâo, Editora Saraiva, Sâo Paulo, pp. 275-276.

77 Para un análisis más amplio que el más esquemático que aquí hacemos, cfr. Fernández SeGado, Francisco (2008). "El control de las omisiones legislativas por el "Bundesverfassungsgericht"”, en Teoría y Realidad Constitucional, $\mathrm{n}^{\circ} 22,2^{\circ}$ semestre 2008, pp. 95 y ss.; en concreto, pp. 108 y ss.

78 TROCKER. Nicolò (1970), pp. 100-101.

79 De la importancia de esa sentencia se hacía eco CAPPelletri, Mauro (1955), en su clásica obra, La giurisdizione costituzionale delle libertà (Primo studio sul ricorso costituzionale), Giuffrè Editore, Milano, 1955, p. 82.

80 Dr. LeCHNER: (1955). "Zur Zulässigkeit der Verfassungsbeschwerde gegen Unterlassungen des Gesetzgebers", en Neue Juristische Wochenschrift (NJW), 8. Jahrgang, Heft 49, 9. Dezember 1955, pp. 1817 y ss.; en concreto, p. 1819. 
modo inequívoco que la inconstitucionalidad podía provenir no sólo por vía de acción, sino también de resultas de una omisión legislativa.

Estas tomas de posición jurisprudencial marcaban una pauta diferencial más que notable respecto de épocas anteriores. Kalkbrenner así lo destacaba en $1963,{ }^{81}$ haciéndose eco de cómo se estaba prestando una creciente atención al problema de las omisiones del legislador, tanto por parte de la jurisprudencia ("Rechtsprechung") como de la literatura jurídica ("Schrifftum”), lo que no había acontecido en la época de la República de Weimar (“die Zeit der Weimarer Republik”), en la que prevaleció la opinión de "la soberanía y el autoritarismo del legislador" ("Souveranität und Selbstherrlichkeit des Gesetzgebers”).

Por lo demás, como ya se dijo, el control llevado a cabo por el $B V e r f G$ no se iba a limitar a las omisiones relativas, sino que se iba a proyectar asimismo sobre las omisiones absolutas, como ejemplificaría a la perfección la también comentada decisión de 29 de enero de 1969.

El instrumental de técnicas decisorias a que iba a acudir el Tribunal Constitucional alemán iba a ser amplio, manifestándose en la pluralidad de variantes de sus sentencias, con las que pretende, y ello debe de ser subrayado, modificar determinados efectos jurídicos de las mismas desde una óptica de justicia material y funcional. ${ }^{82} \mathrm{En}$ el fondo de todo ello, la doctrina iba a converger en una consideración común, que creemos que iba a compendiar con notable claridad la Jueza del Tribunal Constitucional Federal Rupp-v. Brünneck, para quien la institucionalización del BVerfG como órgano independiente que es, no puede tener el sentido de que se confían sus tareas a un gremio que se mueve lejos de la política normal, pues sus sentencias no se limitan a ofrecer ideales teóricos constitucionales ("theoretischen Verfassungsidealen"), sin tener en cuenta los posibles efectos de las mismas ("ohne Rücksicht auf die möglichen Wirkungen seines Urteils"): fiat iustitia, pereat mundus. ${ }^{83}$

A todo ello hay que añadir que este esfuerzo dogmático del $B V e r f G$ se ha hecho particularmente necesario en el caso de las sentencias declaratorias de la inconstitucionalidad de una omisión, al partir el Tribunal de la consideración de que es difícil declarar nulo un vacío jurídico, tesis de la que se haría eco uno de sus presidentes, ${ }^{84}$ tal y como ya señalamos.

Dos son las técnicas decisorias que más relación guardan con el problema de la fiscalización de las omisiones legislativas: las apelaciones al legislador (Appellents-

81 Kalkbrenner, Helmut, p. 41.

82 SCHNEIDER, Hans-Peter (1982), p. 58.

83 RupP-V. BRüNNECK, Wiltraut (1970). "Darf das Bundesverfassungsgericht an den Gesetzgeber Appellieren?”, en Festschrift für Gebhard Müller (Zum 70. Geburtstag des Präsidenten des Bundesverfassungsgerichts), Herausgegeben von Theo Ritterspachund Willi GeiGer, J.C.B. Mohr (Paul Siebeck), Tübingen, pp. 355 y ss.; en concreto, pp. 364-365.

84 ZEIDLER, Wolfgang (1987), p. 48. 
cheidung) y las declaraciones de mera inconstitucionalidad o de inconstitucionalidad sin nulidad (Unvereinbarkeitserklärung). A ellas nos referimos sumariamente.

A) Fue la conocida Jueza del BVerfG Wiltraut Rupp-v. Brünneck quien acuñó por primera vez la expresión "Appell-Entscheidungen" en un trabajo publicado en 1970 en el que se interrogaba acerca de si el Tribunal Constitucional podía apelar al legislador. ${ }^{85}$ La mencionada Jueza iba a considerar injustificado ("unbegründet") el reproche ("der Vorwurf") realizado por algunos frente a estas sentencias, de que las mismas entrañaban "una inadmisible intrusión en la competencia del legislador" ("eines unzulässigen Übergriffes in dem Funktions bereich des Gesetzgebers”), entendiendo, por el contrario, que "sind die Appell-Entscheidungen geradezu eine Bestätigung des vom Bundesverfassungsgericht geübten judicial self-restraint" 86 (las sentencias de apelación son realmente una confirmación de la experimentada judicial self-restraint del Tribunal Constitucional Federal).

Estas decisiones nos ofrecen una pluralidad de tipos, que se presentan como la resultante del hecho de que estas resoluciones emergen en la jurisprudencia del $B V e r f G$ como una constelación de casos diferentes. Todo ello ha propiciado que Schulte llegue incluso a esbozar una tipología bajo el enunciado general de "Fallgruppen von Appellentscheidungen" 87 (grupos de casos de decisiones de apelación). El citado autor diferencia tres casos de grupos típicos ("drei typische Fallgruppen"):88 1) AppeIlentscheidungen con motivo de cambios en la realidad o en la interpretación constitucional ("eines Wandels der Realität oder der Verfassungsinterpretation"); 2) Appellentscheidungen con motivo de un mandato al legislador (un encargo a la legislación en la traducción literal: “aus Anlass unerfüllter Gesetzgebungsaufträgen”), y 3) AppeIlentscheidungen con motivo de la falta de evidencia de una vulneración constitucional ("aus Anlass fehlender Evidenz der Verfassungsvertossses"). Parece patente que sería el segundo tipo el que respondería al supuesto que venimos tratando.

La praxis nos muestra por lo demás, que el legislador ha seguido sin significativas manifestaciones en contrario, las indicaciones del $B V e r f G$, plasmadas por lo general en los fundamentos jurídicos de estas decisiones. Como al efecto escribe Landfried, "Members of Parliament perceive the binding efficacy to last forever and to include nearly every sentence of a decision. That is why an appeal to the Members of Parliament to have more "political self-confidence" is as important as an appeal to the judges to practise more "judicial self-restraint"”. ${ }^{99}$ En definitiva, con esta técnica de la apelación

\footnotetext{
85 Rupp-V. BRÜNNECK, Wiltraut (1970), p. 355.

86 Ibidem, p. 369.

87 Schulte, Martin (1988). “Appellentscheidungen des Bundesverfassungsgerichts”, en Deutsches Verwaltungs Blatt (DVBI), 103. Jahrgang, 15. Dezember 1988, pp. 1200 y ss.; en concreto, pp. 1201-1202.

88 Ibidem, p. 1201.

89 LANDFRIED, Christine (1988). "Constitutional Review and Legislation in the Federal Republic of Germany", en LANDFried, Christine (Ed.), Constitutional Review and Legislation. An International Comparison, Nomos Verlagsgesellschaft, Baden-Baden, 1988, pp. 147 y ss.; en concreto, pp. 166-167.
} 
y reenvío al legislador, a través de una decisión plagada por lo general de directivas, el $B$ VerfG se ha dotado de un instrumento eficaz frente a las omisiones, permitiéndole impulsar la intervención del legislador.

B) Las declaraciones de inconstitucionalidad sin nulidad, de las que ya nos hemos hecho eco, constituyen la otra técnica decisoria a la que ha acudido el BverfG, entre otras finalidades, para hacer frente al control de las omisiones del legislador.

En los primeros años de vida del Tribunal Constitucional Federal, éste vinculó los términos "inconstitucionalidad" (verfassungswidrig) y nulidad (nichtigkeit) a través prácticamente de una relación biunívoca, de tal modo que a la primera se anudaba la segunda. El binomio parecía inescindible, lo que tampoco debía extrañar en exceso si se atendía a la previsión del art. 78 de la Ley del Tribunal (BVerfGG). La situación iba, sin embargo, a cambiar a partir de 1958, al declarar la inconstitucionalidad de una norma sin anudarle la declaración de nulidad. Pestalozza establecería un claro vínculo entre este tipo de decisiones y la declaración de inconstitucionalidad de las omisiones legislativas, razonando que parecía imposible declarar la nulidad de una omisión legislativa ("Es soll nun nicht möglich sein, das gesetzgeberische Unterlassen für nichtig zu erklären"); la decisión, añadía el propio autor, ${ }^{90}$ no puede sino limitarse a confirmar la inconstitucionalidad ("es bewendet bei der Feststellung der Verfassungswidrigkeit").

En 1970, la Ley del Tribunal Constitucional Federal (BVerfGG) iba a ser modificada al objeto de positivar lo que ya venía siendo una pauta consolidada del Tribunal, ignorada hasta ese mismo momento por el texto legal. A tal efecto, se introdujo en el art. 31.2 una específica referencia a la declaración de mera incompatibilidad.

Basta con lo hasta aquí expuesto para que ya pueda comprenderse que no siempre es posible diferenciar con precisión las Appellentscheidungen de las declaraciones de inconstitucionalidad sin pronunciamiento de nulidad (Unvereinbarkeitserklärungen). Como bien se ha indicado, ${ }^{91}$ la simple determinación para que el legislador regule una determinada materia dentro de un cierto plazo (o, añadiríamos por nuestra cuenta, sin fijación de plazo alguno) no expresa un rasgo exclusivo del primer tipo de decisiones, en tanto en cuanto también en las que ahora analizamos se recogen en bastantes ocasiones recomendaciones o exhortaciones expresas para que el legislador promulgue una nueva ley o modifique la fiscalizada en sede constitucional.

Ahora bien, conviene efectuar una puntualización. Las Appellentscheidungen pueden considerarse una modalidad particular de sentencias desestimatorias, y en ello difieren de modo radical de las Unvereinbarkeitserklärungen, que son sentencias de-

90 Pestalozza, Christian (1991), p. 526.

91 Ferreira Mendes, Gilmar (1992). "O apelo ao legislador (Appellentscheidung) na práxis da Corte Constitucional Federal alemana”, en Revista da Faculdade de Direito da Universidade de Lisboa, vol. XXXIII, 1992, pp. 265 y ss.; en concreto p. 279. 
claratorias de la inconstitucionalidad, aunque se separen del tradicional binomio inconstitucionalidad/nulidad.

Digamos finalmente que las declaraciones de mera incompatibilidad responden primigenia, aunque no exclusivamente, a la hipótesis de una exclusión arbitraria de beneficio, que, por lo general, es el resultado de una omisión parcial o relativa, aun cuando en algunos casos se puedan establecer claras analogías con los presupuestos propios de una omisión absoluta.

III. La Corte costituzionale italiana iba asimismo a experimentar un cambio sustancial en lo que hace a la fiscalización de las omisiones legislativas. Sandulli pondría de relieve con notable nitidez tal cambio en un período de tiempo de apenas seis años. $Y$ así, siendo Giudice della Corte costituzionale, en el importante Coloquio internacional sobre la justicia constitucional celebrado en Heidelberg en 1961, podía escribir: "In der italianischen Rechtsordnung ist es nicht denkbar, dass die Unterlassungen des Gesetzgebers den Gegenstand eines verfassungsgerichtlichen Verfahrens bilden”. (En el ordenamiento jurídico italiano no es imaginable que las omisiones del legislador constituyan el objeto de un procedimiento judicial constitucional). ${ }^{92}$

La realidad de los hechos iba pronto a contradecir tal afirmación. En 1967, el mismo Sandulli reconocía ${ }^{93}$ que en la jurisprudencia del juez constitucional italiano más próxima habían emergido, difundiéndose gradualmente, un conjunto de dispositivos "non "eliminativi", ma "creativi" o, se si preferisce "introduttivi" de preceptos nuevos, unas veces en sustitución de los originarios, y otras añadidos a ellos, preceptos sin cuya inserción en la disposición impugnada ésta sería inconstitucional, mientras que su presencia posibilita que tales disposiciones puedan continuar viviendo en el sistema ("e vive di vita nuova").

El primer ejemplo de esta nueva trayectoria lo encontramos en la Sentencia $n^{\circ} 168$, de 1963, en la que la Corte costituzionale vino a declarar la inconstitucionalidad de un precepto de la Ley $\mathrm{n}^{\circ} 195$, de 24 de marzo de 1958, que instituía el "Consiglio Superiore della Magistratura”, con fundamento en que, para las deliberaciones atinentes a los magistrados, exigía la solicitud ("richiesta") del Ministro de Justicia, excluyendo por ello mismo indebidamente (y en ello residía la inconstitucionalidad) la iniciativa del propio Consiglio.${ }^{94}$ A partir de este momento, decisiones análogas iban a sucederse y aun multiplicarse.

92 SANDull, Aldo M. (1962). "Die Verfassungsgerichtsbarkeit in Italien”, en Verfassungsgerichtsbarkeit in der Gegenwart (Länderberichte und Rechtsvergleichung), Herausgegeben von Hermann MosLER, Carl Heymanns Verlag KG, Köln/Berlin, pp. 292 y ss.; en concreto, p. 308.

93 SAndulu, Aldo M. (1967). Il giudizio sulle leggi (La cognizione della Corte costituzionale e i suoi limiti), Giuffrè, Milano, p. 64.

94 Sandulli consideraría esta decisión como "il primo caso di sentenza "creativa" a contenuto "aggiuntivo"”. SANDulul, Aldo M. (1967), p. 65. 
En 1967, Crisafulli podía señalar que no pocas sentencias habían decidido en uno u otro sentido cuestiones de constitucionalidad por omisión, censurando disposiciones por lo que habrían debido explícitamente prescribir y no prescribían. ${ }^{95}$ Tales sentencias, por lo general, eran sentencias interpretativas de desestimación en cuanto que "la lacuna dei testi" le parecía a la Corte rellenable mediante el recurso a otras disposiciones vigentes o a principios generales del Derecho.

De las importantísimas sentencias $\mathrm{n}^{\circ} 62$, de 1971 , y n 190 , de 1970 , ya hemos tenido ocasión de ocuparnos y no volveremos sobre ellas.

Las técnicas de decisión con las que la Corte costituzionale ha enfrentado las omisiones legislativas se han reconducido a la categoría de las llamadas sentencias manipulativas ("sentenze manipolative" o "manipulatrici"), debiéndose tal denominación a Elia, quien la iba a formular en 1965, en un comentario sobre la Sentencia $n^{\circ} 52$, de ese mismo año. ${ }^{96}$ En el léxico oficial de la Corte estas sentencias se identifican como "sentenze di fondatezza parziale", y así son verdaderamente, con la particularidad de que la parte de la disposición legal que se ve afectada no es materialmente distinguible del resto, pues como dice Crisafulli, ${ }^{97}$ "è una parte ideale del significato normativo risultante della disposizione”. Son, pues, sentencias de estimación parcial, bien que respecto de la norma deducible del texto, o si se prefiere, de la disposición, no respecto a ésta, que queda intacta, bien que pase a expresar una norma diferente, o lo que es igual, que pase a tener un significado distinto.

A) Dos son los subtipos que pueden diferenciarse dentro de las sentencias manipulativas: las sentenze additive y las sentenze sostitutive. Respecto a las primeras, la doctrina, generalizadamente, las identifica como aquellas en las que la Corte declara la inconstitucionalidad "della omessa previsione di qualcosa" por una disposición ${ }^{98}$ o aprecia su inconstitucionalidad "nella parte in cui non prevede alcunché". ${ }^{99}$ Quiere ello decir que el juez constitucional aprecia en la disposición que va a considerar inconstitucional un alcance normativo menor del que debería tener. Las sentencias aditivas se han vinculado a través de una relación muy estrecha con el principio de igualdad y con los dere-

95 CrISAfull, Vezio (1967). "Le sentenze «interpretative» della Corte costituzionale", en Rivista trimestrale di Diritto procedura civile, anno XXI, $\mathrm{n}^{\circ} 1$, marzo, pp. 1 y ss.; en concreto, p. 12.

96 ELIA, Leopoldo (1965). "Divergenze e convergenze della Corte costituzionale con la magistratura ordinaria in materia di garanzie difensive nell'istruzione sommaria”, en Rivista italiana di Diritto e procedura penale, nuova serie, anno VIII, 1965, pp. 537 y ss.; en concreto, p. 562. "La Corte costituzionale -escribe Elia- mediante sentenze di accoglimento parziale (che chiamarei manipolative, stavolta in senso buono), considera come contenuto della legge, onde eliminarlo, una entità che è cresciuta contro la legge, anche se innestandosi su di essa: e dichiara si illegittimo ("in quanto" o "nella parte" idealmente scindibile) un testo, ma solo per salvarne la sostanza originaria, conforme a Costituzione, per ripristinare la volontà del legislatore contraddetta da quella dei giudici".

97 Crisafulli,Vezio (1984). "La Corte costituzionale ha vent'anni”, p. 80.

98 CrISAfulul, Vezio (1984). Lezioni di Diritto costituzionale, vol. II (L'ordinamento costituzionale italiano. Le fonti normative. La Corte costituzionale), $5^{\text {a }}$ edizione riveduta, (Padova, CEDAM), p. 403.

99 ZaGrebelSKY, Gustavo (1977). La giustizia costituzionale, (Bologna, Il Mulino), p. 157. 
chos sociales. Hace una treintena de años, Zagrebelsky destacaba ${ }^{100}$ que el supuesto de más frecuente recurso a este tipo de sentencias era aquél en que se trataba de restablecer el principio de igualdad, violado por disposiciones irrazonablemente discriminatorias, al prever una de ellas "qualcosa di più" respecto a lo que para otra categoría de supuestos y destinatarios se establecía por otra norma. Con frecuencia, también en situaciones de privilegios a eliminar se iba a recurrir a este tipo de decisiones, con las que, en último término, se pretendía la generalización del privilegio o beneficio.

B) Las sentenze sostitutive son aquellas a las que recurre la Corte en aquellos supuestos en que la ley prevé algo, mientras que, constitucionalmente, debería disponer otra cosa. En tales casos, el juez constitucional italiano declara la inconstitucionalidad de una ley en cuanto (en la parte) contiene una cierta prescripción antes que otra.

Ejemplo clásico de este tipo de decisiones lo constituye la Sentencia de 17 de febrero de $1969, n^{\circ} 15$. En ella, la Corte consideró constitucionalmente ilegítimo el apartado tercero del art. 313 del Código Penal, que preveía la facultad del Ministro de Justicia para conceder autorización para promover la acción de la justicia por el delito de ultraje a la propia Corte costituzionale ("vilipendio della Corte costituzionale"). La declaración de inconstitucionalidad iba a fundamentarse en la consideración de que tal competencia era lesiva de la posición institucional propia del juez constitucional, que exigía que la concesión de dicha autorización correspondiese a la misma Corte costituzionale. ${ }^{101}$ Ello se traducía, primero, en la invalidación de la disposición penal, y después, en la conversión del fundamento mismo de la inconstitucionalidad en norma vinculante, atribuyendo a la propia Corte la competencia atribuida al Ministro por el legislador. ${ }^{102}$

Aunque es evidente que en el segundo tiempo del pronunciamiento -Picardi ha caracterizado estas decisiones como un mecanismo de pronunciamiento "in due tempi" ${ }^{103}$ - la Corte, tras la ablación de la disposición, se encuentra ante un fenómeno de incomplitud que supera a través de la reconstrucción del tejido normativo, es lo cierto que este tipo de sentencias no parece especialmente útil para hacer frente a las omisiones legislativas, pues presupone la eliminación de una norma, no la ausencia de la misma, si bien tampoco cabe descartar de raíz que tal norma genere algún tipo de omisión relativa. En último término, concordamos con Pizzorusso ${ }^{104}$ en que el proble-

100 ZaGReBelSky, Gustavo (1977), p. 162.

${ }^{101}$ En la sentencia se declara la ilegitimidad de la norma penal "nei limiti" en que la misma atribuye "il potere di dare l'autorizzazione a procedere per il delito di vilipendio della Corte costituzionale al Ministro di grazia e giustizia anziché alla Corte stessa".

102 Paladin identificó las sentencias que siguen la pauta de la $n^{\circ} 15$, de 1969 , como las decisiones que se hallan "empernadas" ("imperniate"), o lo que es igual, sujetas por el perno de la conjunción anziché. PAladin, Livio (1991). Diritto costituzionale, (Padova, CEDAM), p. 778.

103 PICARDI, Nicola (1977). "Le sentenze "integrative» della Corte costituzionale", en la obra colectiva, Aspetti e tendenze del Diritto costituzionale. Scritti in onore di Costantino Mortati, Giuffrè Editore, Milano, vol. $4^{\circ}$, pp. 597 y ss.; en concreto, pp. 632-633.

104 Pizzorusso, Alessandro (1984). "El Tribunal Constitucional italiano”, en la obra colectiva, Tribunales Constitucionales Europeos y Derechos Fundamentales, Centro de Estudios Constitucionales, Madrid, pp. 233 y ss.; en concreto, pp. 261-262. 
ma subyacente a este tipo de decisiones no difiere sustancialmente del que se plantea con las sentencias aditivas.

C) Una nueva categoría de decisiones de notable relevancia se ha podido identificar en la década de los ochenta, no obstante poderse considerar de modo genérico como decisiones aditivas; nos referimos a las llamadas "sentencias aditivas de principio", a través de las cuales la Corte costituzionale, en términos de Anzon, ${ }^{105}$ ha proseguido "in quella incessante e preziosa opera di acrescimento del proprio strumentario". ${ }^{106}$

Estas decisiones, como regla, se limitan a proclamar un principio abstracto y muy general, lo que se traduce en que "non esistano di individuazione di norme univoche, precise e compiute capaci di rimediare all'omissione della legge impugnata"; ${ }^{107}$ consiguientemente, la sentencia constitucional podría generar una situación capaz de dar lugar a las incidencias jurisprudenciales más diversas, con graves repercusiones sobre el principio de seguridad jurídica y sobre el mismo principio de igualdad en la aplicación de la ley.

Es evidente, pues, que este tipo de decisiones no están ni mucho menos exentas de problemas y dificultades. Pero, desde luego, también ofrecen indudables ventajas sobre otros tipos de sentencias. De entrada, evitan que el juez constitucional se convierta en legislador, que es lo que acontece con las sentencias aditivas clásicas, y por otra parte, en cuanto que, como regla general, viabilizan la eficacia inmediata del principio proclamado por la Corte, a través de la intervención de los jueces ordinarios, aunque sea con la limitación de su intervención in casu, evitan el efecto de parálisis que puede acompañar a otro tipo de decisiones constitucionales, como, por ejemplo, las apelaciones al legislador. Por lo demás, en el ámbito específico de los derechos prestacionales, nos parece que este tipo de resoluciones ha desempeñado un rol harto notable y digno de ser positivamente valorado.

D) Al margen de las decisiones manipulativas, nos encontramos con las sentenzemonito, a cuyo través la Corte recurre a la técnica de dar avisos, sugerencias o advertencias (monito) al legislador. El proceso constitucional se cierra con una decisión de inadmisibilidad o de desestimación por falta de fundamento, pero en sus motivaciones jurídicas el juez constitucional acoge una invitación dirigida al legislador para que éste intervenga, regulando de forma diferente la materia y eliminando las incongruencias que la disciplina puede acoger a juicio de la Corte. Aunque no sea el supuesto más frecuente, qué duda cabe de que esas incongruencias, en ocasiones, pueden ser la resultante de una omisión legislativa.

\footnotetext{
105 Anzon, Adele (1992). "Nuove tecniche decisorie della Corte costituzionale”, en Giurisprudenza Costituzionale, ann XXXVII, fasc. 4, Luglio/Agosto 1992, pp. 3199 y ss.; en concreto, p. 3199.

106 La primera de las decisiones que suscita un cierto eco entre la doctrina es la $n^{\circ} 497$, de 27 de abril de 1988. Puede verse en Giurisprudenza Costituzionale, anno XXXIII, 1988, fasc. 3, pp. 2209 y ss.

107 Anzon, Adele (1992), p. 3216.
} 
IV. En resumen, el Bundesverfassungsgericht y la Corte costituzionale ejemplifican cómo los Tribunales Constitucionales, -pues a ellos se podrían añadir otros, como el juez constitucional español- con una enorme creatividad, han acomodado la técnica de sus decisiones a las necesidades ante las que les ha ido situando el paso del tiempo y los nuevos problemas jurídicos que la evolución social y las nuevas demandas sociales han ido planteando. En todo ello creemos que han tenido mucho que ver las exigencias dimanantes del Estado social, como sería el caso del principio de igualdad material y de los derechos de naturaleza prestacional. Y tal actuación ha sido especialmente útil en lo que hace al control de las omisiones legislativas, fiscalización ésta en gran medida responsable de las técnicas decisorias a las que acabamos de referirnos.

En definitiva, los órganos constitucionales aludidos no han sido insensibles ante las omisiones del legislador vulneradoras de la Norma suprema, no obstante no prever los respectivos ordenamientos instrumentos procesales específicos encaminados a su fiscalización.

\section{B) La constitucionalización de instrumentos procesales de control de las inacciones del legislador}

I. Será la Constitución de la República Socialista Federal de Yugoslavia, promulgada el 21 de febrero de 1974, la primera que contemple un instrumento específico de control de las omisiones legislativas. A tenor de su art. 377: "Si el Tribunal Constitucional de Yugoslavia hiciere constar que un órgano competente no hubiere dictado las normas necesarias para la ejecución de las disposiciones de la Constitución de la RSFY, de las leyes federales y de otras prescripciones y actos generales federales, estando obligado a dictarlas, informará de ello a la Asamblea de la República”.

Esta nueva modalidad de control era plenamente coherente con la visión que de la justicia constitucional se iba a tener en los países socialistas, en los que se iba a subrayar la trascendencia del control "positivo" de la constitucionalidad de las leyes. Mientras en los países occidentales el control de constitucionalidad se presenta como un control "negativo", en la medida en que permite paralizar toda actuación del poder legislativo contraria a la Constitución, tal concepción será considerada por el pensamiento socialista como absolutamente insuficiente. Roussillon ha subrayado ${ }^{108}$ la importancia que los teóricos del pensamiento socialista iban a dar a la necesidad de velar para que el legislador respetara "positivamente" la Constitución que desarrolla. Tal posición puede quedar ejemplificada en las siguientes reflexiones de Naschitz: "The constitutionalism -escribe el mencionado autor ${ }^{109}$ - does not imply only the negative

108 Roussillon, Henry (1977). "Leproblème du contrôle de la constitutionnalité des lois dans les pays socialistes”, en Revue du Droit Public, n 1-1977, Janvier/Février, pp. 55 y ss.; en particular, pp. 97-103.

109 NASCHITZ, A. (1970). "Introduction aux règles de contrôle de la constitutionnalité et de la légalité dans l'activité étatique socialiste”. Cours de la Faculté Internationale pour l'Enseignement du Droit comparé 
obligation not to adopt a legal regulation inconsistent with the constitution, but also the positive obligation to adopt all the necessary legal regulation, in the absence of which the constitutional norm would remain only an abstract principle”. Esta visión casaba a la perfección con el rol llamado a jugar por el Tribunal Constitucional yugoslavo como órgano de garantía de la Constitución en el control de las omisiones del legislador y de los restantes poderes públicos.

Más aún, ya en el debate constituyente, el presidente de la Comisión de Coordinación (en realidad, la Comisión constituyente), Edvard Kardelj, iba a dejar expuesto con meridiana claridad el peculiar rol llamado a cumplir por el Tribunal Constitucional. "La Cour constitutionnelle -subrayaría Kardelj ${ }^{110}$ - ne saurait être un organe purement judiciaire qui se contenterait d'examiner, de manière statique et d'un point de vue juridique formel, les phénomènes et problèmes en matière d'organisation constitutionnelle... Dans ce sens, la Cour constitutionnelle prendra, avec la souplesse voulue, des initiatives politiques...”.

Es cierto que, constatada la omisión legislativa inconstitucional (o en su caso la omisión reglamentaria ilegal), el Tribunal debía de limitarse a informar de ello a la Asamblea de la República, no cabiéndole ni exigir que la Asamblea dictara la pertinente norma legal, ni tampoco fijarle un plazo para que lo hiciera. Sin embargo, esta supuesta pasividad del Tribunal, una vez denunciada ante la Asamblea la omisión inconstitucional, podía verse contrarrestada a través de otros mecanismos. Y así, por poner un ejemplo, el art. 376 de la Constitución facultaba al Tribunal para presentar a la Asamblea Federal propuestas para la promulgación de nuevas leyes (también para la modificación de las existentes) y para la adopción de otras medidas encaminadas a asegurar los principios de constitucionalidad y legalidad y a amparar los derechos de la autogestión y los restantes derechos y libertades de los ciudadanos y de las organizaciones y comunidades autogestionadas. Quiere ello decir, que en caso de inconstitucionalidad por omisión legislativa, al Tribunal le era perfectamente posible ejercer una suerte de iniciativa legislativa, en la dirección que ya había establecido la Constitución de 1963, proponiendo la promulgación de nuevas leyes y la adopción de cualesquiera otras medidas normativas.

II. Portugal sería el primer sistema democrático de corte occidental en recepcionar un instituto procesal de control de las omisiones del legislador. La Constitución de 1976 nació de una revolución y nos parece indiscutible que, en su redacción original, debe mucho de su contenido al ideario político revolucionario castrense, esto es, al espíritu subyacente en los militares que llevaron adelante la Revolución de Abril. Como dirían Canotilho y Moreira, ${ }^{111}$ al margen ya de que la Constitución, como muchas

(langue anglaise), Strasbourg, 1970, p. 19. Cit. por Roussılıon, Henry. "Le problème du contrôle de la constitutionnalité des lois...", op. cit., p. 98, nota 166.

110 Tomamos la cita de Zakrzewska, J. (1972): "Le contrôle de la constitutionnalité des lois dans les États socialistes”, en Res Publica (Revue de l'Institut Belge de Science Politique), vol. XIV, 1972, n 4, pp. 771 y ss.; en concreto, p. 777.

111 Gomes Canotilho, J.J. y Moreira, Vital (1978): Constituiçâo da República Portuguesa. Anotada, Coimbra Editora, Coimbra, p. 8. 
otras, tuviese un origen revolucionario, la Carta constitucional era, por su propio contenido, una Constitución característicamente post-revolucionaria. Baste para constatarlo con recordar la recepción y garantía constitucional de las transformaciones revolucionarias en el ámbito económico. Este peculiar carácter de la Constitución de 1976 se iba a traducir en un más que notable dirigismo constitucional.

No ha de extrañar a la vista de tales rasgos constitucionales que amplios sectores de la doctrina vincularan el carácter pragmático-dirigista de la Constitución con la aparición del instituto de la fiscalización de las omisiones legislativas, con la vista puesta en la apreciación de su inconstitucionalidad. ${ }^{112}$

No cabe olvidar, adicionalmente, que fue el MFA (Movimiento de las Fuerzas Armadas) quien propugnó el instituto de control que analizamos. Además, en un primer momento, no será un Tribunal Constitucional el órgano llamado a verificar tal fiscalización, sino el órgano que encarnaba el poder revolucionario original (el Conselho da Revoluçâo). Y el MFA, lo que es bien significativo, en su primera propuesta, ulteriormente modificada tras la negociación con los partidos que habían obtenido representación en la Asamblea Constituyente, en perfecta sintonía con el modelo yugoslavo que defendiera Edvard Kardelj, propondría que el Consejo de la Revolución fuese mucho más que un órgano de control "negativo", en cuanto que se le otorgaba no sólo el control "positivo" del legislador, esto es, la fiscalización de sus omisiones, sino, llegado el caso, una función auténticamente legislativa: la de suplir al legislador reticente a la adopción de las medidas legislativas que le hubieran sido encomendadas.

La trascendental reforma constitucional portuguesa de 1982 iba a mantener el instituto de la inconstitucionalidad por omisión (art. 283), aun cuando el mismo estuviese lejos de suscitar un pleno consenso. Miranda recuerda ${ }^{113}$ que entre las cuestiones graves que en el ámbito de la justicia constitucional dividían a la Asamblea de la República llamada a reformar la Constitución, se encontraba la de mantener o no la fiscalización de las omisiones supuestamente inconstitucionales, lo que puede resultar un tanto sorprendente si se recuerda que la Constitución de 1976 incorporaba el instituto en cuestión dentro de los límites materiales vedados para la reforma.

La praxis del instituto analizado ha sido decepcionante, pues desde 1982 hasta hoy, tan sólo el Provedor de Justiça ha requerido (en siete ocasiones) el control de la inconstitucionalidad de las omisiones legislativas, habiendo reconocido el Tribunal en dos de esos casos la inconstitucionalidad. No ha de extrañar por ello mismo que la ineficacia sea el juicio en el que convergen gran cantidad de autores al valorar el

112 En tal sentido, Canotilho, de modo rotundo, consideraba que la expresa consagración de la inconstitucionalidad por los comportamientos omisivos del legislador era una consecuencia lógica y necesaria del carácter predominantemente prescriptivo y dirigente de la Ley Fundamental de 1976. GOMES CANOTILHO, J.J. (1982). Constituiçâo dirigente e vinculaçâo do legislador (Contributo para a compreensâo das normas constitucionais programáticas) (Coimbra Editora, Coimbra), p. 354.

113 Miranda, Jorge (1991). Manual de Direito Constitucional, tomo II (Constituiçâo e inconstitucionalidade), $3^{\text {a }}$ ediçâo revista, (Coimbra, Coimbra Editora), p. 405. 
instituto desde la óptica de su operatividad. Medeiros ha calificado el instituto de casi inofensivo. ${ }^{114}$ A su vez, Pereira da Silva, enjuiciándolo desde una óptica comparada, considera que el art. 283 de la Constitución ha generado una situación paradójica, por cuanto nos muestra que uno de los pocos textos que acoge un precepto específico sobre esta modalidad de fiscalización termina siendo aquel que, en la realidad, menos control hace de este tipo de vicio. ${ }^{115}$

No faltan, desde luego, quienes, como Miranda, creen que, frente a la consideración de que se trata de un mecanismo platónico, porque la verificación de la existencia de la omisión tan sólo autoriza al Tribunal Constitucional a dar conocimiento de ello al órgano legislativo, el mecanismo no es tan platónico como se supone, porque la experiencia portuguesa muestra que casi siempre, de inmediato, el legislador se ha sentido obligado, por la fuerza del auténtico impulso legislativo latente en el instituto, a corregir su falta, esto es, la medida legislativa omisa. ${ }^{116}$

En cualquier caso, nos parece evidente que difícilmente podrá ser operativo un instituto al que no se recurre, y desde esta perspectiva la escasez de iniciativas encaminadas al desencadenamiento de este control se revela, a nuestro modo de ver, como la causa básica de su inoperatividad. Y todo ello, qué duda cabe, tiene bastante que ver con lo restringido de la legitimación para recurrir.

III. Brasil va a seguir a Portugal en el diseño del instituto de control de las omisiones del legislador y del poder reglamentario, consagrando en el art. 103 de la Constitución de 1988 la açâo de inconstitucionalidade por omissâo, que se contempla tanto respecto de omisiones del poder legislativo como del poder reglamentario. A ello se añadirá el instituto procesal del mandado de injunçâo, un mecanismo de tutela de los derechos vulnerados de resultas de su inviabilización desencadenada por la ausencia de una norma reguladora.

La consagración de estos mecanismos procesales es tributaria de las propias circunstancias históricas del Brasil, que en esencia pueden compendiarse en la muy arraigada tendencia al falseamiento de las previsiones constitucionales, particularmente de las relativas a derechos, y dentro de ellas, de las que proclamaban derechos de naturaleza socio-económica, derechos prestacionales, de resultas de su sistemática falta de desarrollo por el legislador, en definitiva, de las omisiones legislativas. La doctrina brasileña se ha hecho eco de ello en repetidas ocasiones. Muchos ejemplos podrían traerse a colación. Nos limitaremos a uno. "Há uma espécie de tradiçâo institucional perversa em

\footnotetext{
${ }^{114}$ Medeiros, Rui (1999). A Decisâo de Inconstitucionalidade (Os autores, o conteúdo e os efeitos da decisâo de inconstitucionalidade da lei), (Lisboa, Universidade Católica Editora), p. 520.

115 Pereira da Silva, Jorge (2003). Dever de legislar e protecçâo jurisdicional contra omissôes legislativas (Contributo para uma Teoria da Inconstitucionalidade por Omissâo), (Lisboa, Universidade Católica Editora), p. 17.

116 MirandA, Jorge (2003). “O Tribunal Constitucional Português em 2002”, en Anuario Iberoamericano de Justicia Constitucional, $\mathrm{n}^{\circ}$ 7, 2003, pp. 561 y ss.; en concreto, p. 576.
} 
nossa história -escribe Siqueira Castro ${ }^{117}$ - consistente na sistemática sonegaçâo das condiçôes de exercício de direitos constitucionalmente consagrados, pelo expediente da paralísia das instâncias regulamentadoras". Y el propio autor considera que fue para evitar que tales estrategias conservadoras de encubrimiento de derechos se perpetuasen, para lo que la Asamblea Constituyente creó el mandado de injunçâo. Y por nuestra parte, añadiríamos que idéntico argumento vale asimismo para explicar el nacimiento de la açâo direta de inconstitucionalidade por omissâo.

Más allá de esta circunstancia particular de Brasil (aunque se puede vislumbrar en otros muchos países del área latinoamericana), es claro que uno de los problemas fundamentales del Derecho constitucional de nuestro tiempo es el de encontrar los medios adecuados para convertir en efectivos, esto es, en disfrutables por sus beneficiarios, aquellos derechos que, por la ausencia de una legislación integradora, permanecen inocuos hasta que la misma se dicte, problema que, innecesario es decirlo, se agrava en el caso de los derechos de naturaleza prestacional. A ello habría desde luego que añadir, con una perspectiva más general, que la búsqueda de nuevos medios de garantía de los derechos ha sido siempre uno de los mayores retos del constitucionalismo, por lo que no ha de extrañar que algunos hayan cifrado la evolución constitucional en el proceso de permanente búsqueda de los instrumentos más idóneos con los que hacer frente a las nuevas amenazas que progresivamente van surgiendo para los derechos constitucionales. Y si se atiende de modo específico a la Carta de 1988, de inmediato se capta su enorme carga de materia programática, por así llamarla, y en particular, su gran volumen de derechos de naturaleza prestacional.

De resultas de todo ello, la diversidad de instrumentos de naturaleza procesal constitucional que la Constitución de 1988 recepciona no sólo es coherente con el acentuado carácter "dirigente" de esta Carta, que tiene su más inmediato reflejo en la pluralidad de sus enunciados programáticos, sino también con esa perversa tradición histórica del reticente legislador brasileño.

Las ideas que preceden quedaron de algún modo compendiadas en alguna de las reflexiones vertidas por el presidente de la Asamblea Constituyente, Ulysses Guimarâes, en su intervención con ocasión del acto de la promulgación de la Constitución: "A Assembléia Nacional Costituinte rompeu contra establishment, investiu contra a inércia, desafiou tabus". ${ }^{118}$

Existe un cierto consenso doctrinal acerca de la escasa eficacia práctica que la açâo de inconstitucionalidade por omissâo ha tenido hasta hoy. ${ }^{119}$ Streck ha llegado a ha-

117 SiqueIra Castro, Carlos Roberto (2006). O devido processo legal e os princípios da razoabilidade e da proporcionalidade, $4^{\text {a }}$ ed. (Rio de Janeiro, Editora Forense), p. 379.

118 El discurso del presidente de la Asamblea Constituyente puede verse en BonAvides, Paulo y PAES DE Andrade (1991): História Constitucional do Brasil, $3^{\text {a }}$ ed., Editora Paz e Terra, Rio de Janeiro, pp. 921925; la cita, en p. 921.

119 En tal sentido, entre otros, BARBOSA MOREIRA, José Carlos (2003). "El control judicial de la constitucionalidad de las leyes en el Derecho brasileño: un bosquejo”, en Eduardo FERrER MAC-GreGor (coordinador). 
blar de una "morte prematura" de esta acción, ${ }^{120}$ para añadir: "A quase total ineficácia da açâo de inconstitucionalidade por omissâo corre na contramâo da relevante circunstância de que esse instituto é produto de um novo conceito de constitucionalismo umbilicalmente ligado à concepçâo intervencionista e ao plus normativo que assume o Direito (constitucional) no Estado Democrático de Direito”.

Al margen ya de los escasísimos casos en que se ha admitido por el Supremo Tribunal Federal la existencia de una omisión contraria al texto constitucional (en los primeros quince años de vigencia de la Constitución tan sólo dos acciones de inconstitucionalidad por omisión tuvieron éxito), la doctrina ha puesto de relieve que existen decenas de dispositivos constitucionales que no han sido desarrollados por los poderes públicos, no obstante lo cual no se ha recurrido al instituto de la acción directa de inconstitucionalidad por omisión.

Tampoco la praxis del mandado de injunçâo -que, no obstante no ser un instrumento de control normativo sino de tutela de los derechos constitucionales, converge con la açâo de inconstitucionalidade por omissâo en su común existencia como instrumentos con los que hacer frente a las omisiones de los poderes públicos vulneradoras de normas constitucionales- es mucho más satisfactoria. En el año 2001, Guerra Filho hablaba ${ }^{121}$ del "estado de parálisis" en que se encontraba el instituto, y Othon Sidou, por las mismas fechas, expresaba sus dudas acerca de la utilidad de la contribución jurisprudencial del Supremo Tribunal Federal a efectos del perfeccionamiento del instituto. ${ }^{122}$

Cabe, sin embargo, hacer una matización de interés. Las tres importantes sentencias dictadas por el Supremo Tribunal Federal el 25 de octubre de 2007 han supuesto un notabilísimo cambio de posicionamiento jurisprudencial, ${ }^{123}$ posibilitando a través de ellas el ejercicio de un derecho constitucional (en los tres casos, el derecho de huelga de los funcionarios públicos) no obstante la inexistencia de una ley, constitucionalmente exigida, en desarrollo del mismo. Habrá con todo que esperar para ver si este notable cambio jurisprudencial se consolida.

IV. Un año después de que el control de las omisiones legislativas fuese recepcionado en Brasil iba a serlo también en Hungría. La Ley ${ }^{\circ}$ XXXII, de 1989 , sobre el

Derecho Procesal Constitucional, $4^{\text {a }}$ ed., Editorial Porrúa/Colegio de Secretarios de la Suprema Corte de Justicia de la Nación, México, tomo III, pp. 1991 y ss.; en concreto, p. 2001.

120 STRECK, Lenio Luiz (2004). Jurisdiçâo Constitucional e Hermenêutica (Uma Nova Crítica do Direito), $2^{\text {a }}$ ediçâo (Rio de Janeiro, Revista, Editora Forense), p. 788.

121 Guerra Filho, Willis Santiago ( 2001). Processo Constitucional e Direitos Fundamentais, $2^{\text {a }}$ ediçâo (Sâo Paulo, Revista Celso Bastos editor), p. 111.

122 Othon Sidou, J. M. (2002). "Habeas Corpus", Mandado de Segurança, Mandado de Injunçâo, "Habeas Data”, Açâo Popular, 6a ediçâo, Editora Forense, Rio de Janeiro, p. 284.

123 En su jurisprudencia tradicional, el Supremo Tribunal Federal venía equiparando los efectos del mandado de injunçâo a los propios de la açâo direta de inconstitucionalidade por omissâo, traduciéndose la apreciación por el Tribunal de la violación de un derecho de resultas de la falta de su regulación en una comunicación al legislativo para que adoptara las providencias oportunas, comunicación que, por lo general, era ignorada por el poder legislativo. 
Tribunal Constitucional, ${ }^{124}$ en su art. $1^{\circ}$, apartado e/, incluye entre las atribuciones del juez constitucional magiar la supresión de la inconstitucionalidad que se manifieste a través de la omisión legislativa, regulando el art. 49 los aspectos fundamentales del procedimiento de control de las omisiones del legislador.

Uno de los aspectos más discutibles, si es que no el que más, de la regulación de este instituto tiene que ver con la legitimación activa. A tenor del art. 49.1 del mencionado texto legal, este procedimiento puede ser iniciado de oficio, por el propio Tribunal, o a instancia de cualquiera. El hecho de que el propio Tribunal Constitucional pueda tomar la iniciativa de este procedimiento, actuando ex officio, lo que no es posible respecto del control de constitucionalidad por acción a posteriori, abstracto o concreto (aunque la Ley también habilita al Tribunal para actuar de oficio en el que podríamos denominar "control de convencionalidad", esto es, en el control de la conformidad de cualquier disposición jurídica con una convención o tratado internacional, control que puede llevarse a cabo tanto por acción como por omisión, en este último caso, al dejar de dictar el Parlamento un texto legislativo exigido por la convención o tratado), se ha visto ${ }^{125}$ como una prueba de lo importante que el legislador ha considerado la supresión de las violaciones de la Constitución llevadas a cabo por omisión.

No vemos esta legitimación de oficio de la misma forma. Connatural a cualquier órgano judicial, más aún a un órgano de la justicia constitucional, pues al mismo le está encomendada la trascendental función de enjuiciar, entre otros, los productos normativos del legislador, es su carácter rogado, que como es bien sabido implica que no puede iniciar un procedimiento si no es formalmente instado a ello por quien se halle legitimado al efecto, lo que es obvio que se sitúa en las antípodas de una actuación ex officio. Y no cabe dudar en absoluto de la naturaleza jurisdiccional de un órgano como el que nos ocupa. Hace ya medio siglo, Leibholz escribía algo que sigue teniendo plena vigencia: "Gewiss sind die Verfassungsgerichte Gerichte, und zwar selbständige und unabhängige Gerichte, die wie andere Gerichte eine rechtsprechende Tätigkeit im materiellen Sinne entfalten und Rechtsfragen zu entscheiden haben". ${ }^{126}$ (Indudablemente, el Tribunal Constitucional es un Tribunal, un Tribunal independiente y autónomo, que, como otros Tribunales, desarrolla una actividad jurisprudencial en sentido material y que tiene que decidir sobre cuestiones jurídicas).

Las particularidades de la justicia constitucional no deben en modo alguno de llegar al extremo de privar a los Tribunales Constitucionales de aquellos rasgos que los hacen reconocibles como jurisdicción, que les otorgan su identidad jurisdiccional. Y

${ }_{124}$ Puede verse el texto de esta ley en Annuaire Internationale de Justice Constitutionnelle, VI, 1990, pp. 867-880.

125 Adam, Antal (200). "La Cour constitutionnelle en Hongrie”, en Giustizia costituzionale e sviluppo democratico nei paesi dell'Europa centro-orientale, a cura di de VerGottinI, Giuseppe (Torino, G. Giappichelli Editore), pp. 207 y ss.; en concreto, p. 224.

126 Gerhard LeiBHOLz (1957). “Einleitung”, en “Der Status des Bundesverfassungsgerichts” (Gutachten, Denkschriften und Stellungnahmen mit einer Einleitung), en Jahrbuch des Öffentlichen Rechts der Gegenwart, band 6, pp. 110 y ss.; en concreto, p. 111. 
entre ellos podríamos recordar algunos de los que Cappelletti denominara reglas fundamentales de la "justicia natural", ${ }^{127}$ nacidas antes de la consolidación de los sistemas de common law, en cuanto frutos de la sabiduría latina, como sería el caso de aquellas reglas que con sin par nitidez reflejan los aforismos "ubi non est actio, ibi non est jurisdictio" o "nemo judex sine actore", o la máxima alemana "wo kein Kläger ist, da ist auch kein Richter" (donde no hay demandante, no hay juez).

Quizá la iniciativa conferida al Tribunal Constitucional húngaro para iniciar ex officio este procedimiento sea en alguna medida deudora de la concepción que de la justicia constitucional se tenía en los países socialistas, que puede ejemplificar el Tribunal Constitucional yugoslavo en 1974, y a la que ya nos hemos referido, pero esa visión, innecesario es decirlo, poco, o más bien nada, tiene que ver con la visión que de la justicia constitucional se tiene en la Europa democrática, a la que ya pertenece Hungría.

V. El instituto que venimos analizando ha sido recepcionado, además de ya en Brasil, en otros diversos países de América Latina, en algunos de ellos, como es el caso de Argentina y de México, no en el orden federal, sino en el de las Provincias integrantes de la Nación Argentina y en el de las entidades federativas mexicanas. La Provincia argentina de Río Negro o los Estados mexicanos de Veracruz, Tlaxcala, Chiapas y Quintana Roo han acogido con una u otra denominación institutos similares. ${ }^{128}$ En algunos de ellos, el rol que ha sido conferido al órgano jurisdiccional de control entraña su conversión en un órgano legislativo, lo que supone una grave quiebra respecto de su naturaleza y un brutal atentado contra el principio de la división de poderes, pero de ello nos ocuparemos de modo específico más adelante.

\section{EL DEBATE EN TORNO A LAS VÍAS IDÓNEAS CON LAS QUE HACER FRENTE AL CONTROL DE LAS OMISIONES RELATIVAS}

Particularmente problemática se ha revelado en sede dogmática la cuestión de dilucidar la mayor o menor idoneidad de las vías de control abstracto y concreto para la fiscalización de las omisiones relativas, esto es, de aquellas que entrañan una vulneración del principio de igualdad. Como es obvio, este problema se presenta como real en aquellos países, como Portugal, en que existe un instituto procesal de control abstracto.

La estrechísima conexión entre omisión legislativa y vulneración de derechos constitucionales de resultas de la inacción del legislador explica perfectamente que en Alemania y en España, países que cuentan con un específico instituto de tutela en sede constitucional de los derechos y libertades, hayan sido el Verfassungsbeschwer-

127 Cappelletti, Mauro (1990). “Des juges législateurs?” (Étude dédiée à la mémoire de Tullio Ascarelli et d'Alessandro Pekelis). Recogido en la obra recopilatoria de artículos del autor, Le pouvoir des juges, (Paris, Economica/Presses Universitaires d'Aix-Marseille), pp. 23 y ss.; en concreto, pp. 70-71.

128 Cfr. al efecto, Fernández SeGado, Francisco (2009). La justicia constitucional: una visión de Derecho comparado, (Madrid, Dykinson), tomo I, pp. 1112 y ss. 
de y el recurso de amparo los cauces habituales de desencadenamiento de esta fiscalización. Y la misma razón contribuye a explicar que en Italia hayan sido los jueces ordinarios quienes hayan desencadenado el control que nos ocupa con ocasión de su conocimiento de litis concretas en las que habían de aplicarse normas que, a su juicio, eran dudosamente constitucionales.

El argumento precedente adquiere un peso específico mayor en el concreto supuesto a que aludimos: el de las omisiones relativas, que presuponen la existencia de un texto legislativo que genera, por su carácter parcial o incomplitud, un trato diferencial vulnerador del principio de igualdad, que suele desencadenar una exclusión arbitraria de beneficio. Es fácilmente comprensible que sea con ocasión de la aplicación del texto legal, cuando más perceptiblemente se pueda manifestar el vicio de la omisión inconstitucional. En tal argumentación se han apoyado aquellos sectores de la doctrina partidarios de encauzar todo posible control de las inacciones legislativas a través de los antes mencionados cauces procesales, rechazando la constitucionalización de instrumentos específicos de control de las omisiones. No vamos a retornar a esta polémica. Ya nos hemos pronunciado acerca de cómo, a nuestro juicio, la constitucionalización de tales mecanismos procesales, allí donde se ha producido, responde a unas causas perfectamente justificadas. Que la aplicación práctica de esos instrumentos haya sido decepcionante, que, desde luego, lo ha sido, en nada obsta a lo anterior.

El debate en torno a la cuestión abordada ha adquirido perfiles de mayor trascendencia y gravedad en países como Portugal, entre otras razones, porque la existencia de un instituto específico de control de las omisiones ha supuesto, por mor de la interpretación del Tribunal Constitucional, el encauzamiento de la fiscalización de cualquier tipo de omisión, con independencia de que la misma sea absoluta o relativa, a través del mencionado instrumento procesal, lo que no ha dejado de desencadenar serias distorsiones. A ellas pasamos a referirnos.

El problema principal que se suscita en nuestro vecino país es el de la vía procesal a utilizar para el control de las omisiones parciales o relativas. ¿Cabe reconducir su fiscalización al control por acción? Un amplio sector de la doctrina portuguesa se ha mostrado bastante acorde en la conveniencia del control por vía de acción de este tipo de omisiones vulneradoras del principio de igualdad. Así, Miranda ${ }^{129}$ ha admitido tal vía de control siempre que dichas omisiones "acarretem um tratamento mais favorável ou desfavorável prestado a certas pessoas ou a certas categorias de pessoas, e nâo a todas as que estando em situaçâo idêntica ou semelhante, deveriam também ser contempladas do mesmo modo pela lei”. En semejante dirección, Alves Correia ${ }^{130}$ considera que las omisiones relativas, que derivan básicamente de la incomplitud de la medida, pueden dar origen a una "inconstitucionalidade por açâo" por violación del principio de igualdad, y no, por contra, a una inconstitucionalidad por omisión.

129 Miranda, Jorge. (2001). Manual de Direito Constitucional, tomo VI (Inconstitucionalidade e Garantía da Constituiçâo), (Coimbra, Coimbra Editora), p. 290.

130 Alves Correla, Fernando (2001). Direito Constitucional. A Justiça Constitucional, (Coimbra, Almedina), p. 476. 
Es bastante evidente a nuestro entender, que en los casos de omisiones relativas, el control de la inconstitucionalidad por acción será más útil para los ciudadanos que el control por omisión, siempre que el Tribunal Constitucional sea capaz de adoptar algunas de las técnicas decisorias que hemos contemplado al referirnos al $B V e r f G$ o a la Corte costituzionale. No lo será (particularmente cuando la ley establezca un beneficio) si el Tribunal se limita sin más a declarar la nulidad del precepto que genera el trato discriminatorio. Puede pensarse en la posible reparación de la situación inconstitucional a través del control difuso, que en Portugal asumen los tribunales ordinarios; ${ }^{131}$ sin embargo, esta vía procesal presenta el serio problema de que los efectos de las sentencias se circunscriben al caso concreto. Y ello no sólo cuando quien aprecia la inconstitucionalidad es el juez ordinario, sino también cuando quien la verifica es el Tribunal Constitucional. Cabe recordar al respecto que lo normal será que el problema de constitucionalidad termine llegando al Tribunal Constitucional, que para apreciar la inconstitucionalidad de la norma con efectos erga omnes, necesita de la verificación de tal inconstitucionalidad en tres casos concretos; mientras tal triple pronunciamiento no se produzca, los efectos de las sentencias del Tribunal Constitucional se circunscribirán también al caso concreto, todo lo cual, de facto, acentúa la dificultad de proceder con cierta rapidez a la subsanación de la quiebra del principio de igualdad a través de esta vía del control concreto o con ocasión de la aplicación de la ley, en este caso, de la ley parcial generadora de la omisión relativa.

No ha de extrañar por lo expuesto que ciertos autores se hayan mostrado especialmente críticos frente al empleo de la vía procesal del control omisivo para hacer frente a la fiscalización de las omisiones relativas. Ha sido Medeiros quien con más detenimiento se ha ocupado del tema. ${ }^{132} \mathrm{~A}$ su juicio, aún pudiéndose aceptar la aplicación acumulativa de los regímenes de fiscalización de la inconstitucionalidad por acción y por omisión respecto a las leyes que, de resultas de una omisión relativa, se presentan como discriminatorias, no puede aceptarse que, en la opción por uno de ellos, se prefiera el régimen prácticamente inocuo de la fiscalización de la inconstitucionalidad por omisión. La dualidad de fundamentos de la inconstitucionalidad no puede implicar la prevalencia del estatuto más favorable para el mantenimiento de la situación inconstitucional. Por lo mismo, el citado autor cree forzoso reconocer que el régimen de la fiscalización de la inconstitucionalidad por omisión no se aplica a las leyes que conceden derechos con violación del principio de igualdad.

Pereira da Silva, desde una perspectiva más amplia del problema, ${ }^{133}$ puesto que no atiende tan sólo al control de las omisiones relativas, sino a la fiscalización de todo tipo de omisiones, se inclina decididamente a favor de complementar el diseño portugués actual de la açâo de inconstitucionalidade por omissâo a través del reconocimiento de la

\footnotetext{
131 Cfr. al respecto, Fernández Segado, Francisco (2009). La justicia constitucional: una visión de Derecho comparado, tomo I, (Madrid, Dykinson), pp. 778 y ss.

132 Medeiros, Rui (1999), p. 520.

133 Pereira da Silva, Jorge (2003), pp. 167 y ss.
} 
facultad de los tribunales ordinarios de llevar a cabo la fiscalización en el caso concreto de las omisiones legislativas. Para el mencionado autor, la única razón esgrimible para impedir el control concreto de las omisiones inconstitucionales por cualquier tribunal en el caso sub judice, se encuentra en la interpretación literal del art. 204 de la Constitución portuguesa ("Apreciaçâo da inconstitucionalidade"), que al contemplar la fiscalización de la inconstitucionalidad por los órganos jurisdiccionales ordinarios se refiere a las "normas que infrinjan lo dispuesto en la Constitución o los principios en ella configurados”. Al derivar la inconstitucionalidad por omisión de la ausencia de norma (salvo cuando se trate de una omisión relativa), faltaría el objeto de la fiscalización. Y no habiendo fiscalización difusa al amparo del art. 204, tampoco puede haber fiscalización concreta concentrada, porque en ella, de acuerdo con el art. 280 de la propia Carta constitucional lusa, los recursos ante el Tribunal Constitucional han de tener por base una decisión judicial aplicativa de normas o que rechace su aplicación. Tales objeciones no serían en modo alguno impeditivas del control si se optase por una visión normativista de la omisión, con arreglo a la cual, de la inactividad del legislador no resulta una "nada" o un "vacío", sino una prescripción de sentido negativo, o dicho de otro modo, que la inactividad del legislador, inserta en un contexto lógico y teleológico, adquiere la naturaleza, la función y el efecto de una norma negativa o de exclusión.

No ha sido la precedente la interpretación del Tribunal Constitucional portugués. Sus Acuerdos 32/90, 499/97 y 500/99, entre otros, pueden ofrecer una buena muestra de ello.

Por lo demás, innecesario es decir que en el problema que ahora abordamos (control de las omisiones relativas) la objeción precedentemente expuesta aún sería menos pertinente si se piensa en que en tales casos la omisión no es fruto de la ausencia de un texto legislativo, sino de su incomplitud, de su parcialidad.

En definitiva, hemos de reivindicar un rol activo por parte de los jueces y tribunales ordinarios, particularmente en lo que atañe al desencadenamiento del control de las omisiones relativas, a través, allí donde tal instrumento procesal existe, del planteamiento de una cuestión de inconstitucionalidad. Este argumento debería dirigirse en Portugal en favor del conocimiento por esos mismos órganos judiciales -legitimados, como ya se ha dicho, para llevar a cabo un control difuso e in casu de la constitucionalidad- de las omisiones relativas ( $y$ aún diríamos que de las absolutas, cuando la ausencia de un texto legislativo se traduzca en la aplicación de una norma preconstitucional en contradicción con la Norma suprema) supuestamente vulneradoras de la Constitución. En cualquier caso, y a la vista del art. 280 de la Constitución lusa, que prevé un específico recurso ante el Tribunal Constitucional frente a las decisiones de los tribunales ordinarios dictadas tras haber llevado a cabo un control de constitucionalidad, ${ }^{134}$ sería necesario

\footnotetext{
134 A tenor del art. 180.1 del vigente texto de la Constitución portuguesa: "Cabe recurso ante el Tribunal Constitucional de las decisiones de los tribunales: a) Que rechacen la aplicación de cualquier norma con fundamento en su inconstitucionalidad. b) Que apliquen una norma cuya inconstitucionalidad haya sido suscitada durante el proceso".
} 
reivindicar al unísono una reforma de la previsión constitucional del art. 281.3, que exige la declaración de inconstitucionalidad de una norma en tres casos concretos para que tal inconstitucionalidad quede dotada de fuerza obligatoria general. Sólo así podría ser realmente operativo este control.

\section{7. ¿JUEZ CONSTITUCIONAL VERSUS LEGISLADOR?: EL DEBATE SOBRE LOS EFECTOS DE LA DECLARACIÓN DE INCONSTITUCIONALIDAD POR OMISIÓN}

Uno de los más relevantes problemas dogmáticos que suscita la posible declaración de la inconstitucionalidad de una omisión legislativa atañe a los efectos de la misma, y en ello existe una amplia convergencia doctrinal. Como al efecto escribe Ribes, ${ }^{135}$ "la difficulté réside pour le juge constitutionnel dans l'établissement d'un remède approprié à cette pathologie particulière de la loi”. Por supuesto, conviene señalar desde este mismo momento que los efectos en cuestión se hallan lejos de ser unívocos, pues, inexcusablemente, van a depender del tipo de recurso a cuyo través se desencadene el pronunciamiento del juez constitucional.

La búsqueda de una solución se ha revelado especialmente dificultosa en relación al instituto procesal de la acción de inconstitucionalidad por omisión. No en vano en tal caso afloran con particular intensidad problemas de no fácil solución, que en ocasiones conducen a fórmulas antitéticas. Y así, si de un lado las dificultades prácticas de la concreción judicial de las imposiciones del juez constitucional conducen al carácter platónico de que habla Canotilho ${ }^{136}$-refiriéndose al específico instituto portugués de control de las omisiones- de las órdenes, apelaciones o condenas del silencio legislativo, de otro, la salvaguarda de la libertad de configuración del legislador puede no dar mucho más margen a ese carácter de incitación o de reconvención que para el legislador tienen este tipo de sentencias en Portugal o en Brasil.

Digamos desde una perspectiva general, y admitida la capacidad de las sentencias constitucionales de innovar el orden legislativo preexistente, lo que es propio de la función legislativa, que aun reconociendo los peculiares efectos de las sentencias constitucionales, en modo alguno puede confundirse la naturaleza jurisdiccional de las decisiones de un Tribunal Constitucional con el ejercicio de la función legislativa. Es cierto, y así se reconoce pacíficamente por la doctrina, que en su interpretación de la Constitución y del resto del ordenamiento jurídico en conformidad con la misma, el juez constitucional desarrolla una actividad que no se agota en la mera repetición de

\footnotetext{
135 Ribes, Didier (200). "Le juge constitutionnel peut-il se faire législateur? (À propos de la décision de la Cour Constitutionnelle d'Afrique du Sud du 2 décembre 1999)”, en Les Cahiers du Conseil constitutio$n n e l, \mathrm{n}^{\circ}$ 9, Mars 2000/ Septembre 2000, p. 2 del texto al que se accede al través de la página web del Conseil: http://www.conseil-constitutionnel.fr/cahiers.

136 Gomes Canotilho. J.J. (1982), p. 350.
} 
los mandatos jurídicos, sino que comporta también opciones según criterios de oportunidad política. ${ }^{137}$ Ahora bien, el juez constitucional no puede pretender suplantar al legislador en ningún caso, ni tan siquiera con ocasión del control de las omisiones legislativas, ni aunque fuere temporal o provisionalmente. La doctrina no deja al respecto resquicio alguno a la duda. Y así, para von Brünneck, "the constitutional review process may not actually sit in place of the legislature. It must pay regard to the freedom of discretion with which the constitution has provided the legislature. ${ }^{138} \mathrm{Y}$ aunque debe admitirse ciertamente que en el ámbito de la fiscalización en sede constitucional de las omisiones legislativas se favorece la tendencia expansiva del juez constitucional frente al legislador, no puede perderse de vista que uno de los dos grandes peligros que, como recuerda Zweigert, amenazan a un Tribunal Constitucional, es el de un cambio de su naturaleza a través de la usurpación de tareas evidentes del legislador ("eine Usurpation von evidenten Aufgaben des Gesetzgebers"). ${ }^{139}$

Principios constitucionales de la máxima relevancia, como el de la división de poderes, el de la legitimidad democrática del legislador y el del pluralismo, constituyen a nuestro entender barreras infranqueables que impiden la conversión del juez constitucional en legislador en ningún momento ni circunstancia, tampoco con ocasión del control de las omisiones legislativas. Piénsese, por ejemplo, en que el respeto de la libertad configuradora del legislador adquiere particularísima relevancia cuando la norma constitucional ofrece múltiples posibilidades de desarrollo. Como aduce Silvestri en referencia a la Corte costituzionale, aun cuando su reflexión tenga un valor muchísimo más amplio, "la Corte non può e non deve prendere partito quando da una stessa norma costituzionale discendeno possibilità diverse di attuazione". ${ }^{140}$

Ciertamente, no faltan voces proclives a una matizada relativización en este ámbito del principio de división de poderes, no obstante que éste, innecesario es decirlo, sigue desempeñando una función fundamental en el sistema democrático. ${ }^{141}$ En Alemania,

137 SORRENTINO, Federico (1985). "Strumenti tecnici e indirizzi politici nella giurisprudenza della Corte costituzionale”, en Scritti su la Giustizia Costituzionale. In onore di Vezio Crisafulli, (Padova, CEDAM), tomo I, pp. 795 y ss.; en concreto, p. 795.

138 VON BRüNNECK, Alexander (1988). "Constitutional Review and Legislation in Western Democracies", en LANDFrIed, Christine (Ed.), Constitutional Review and Legislation. An International Comparison, (BadenBaden, NomosVerlagsgesellschaft), 1988, pp. 219 y ss.; en concreto, p. 256.

139 ZWEIGERT, Konrad (1976). "Einige rechtsvergleichende und kritische Bemerkungen zur Verfassungsgerichtsbarkeit”, en Bundesverfassungsgericht und Grundgesetz (Festgabe aus Anlass des 25 jährigen Bestehens des Bundesverfassungsgerichts), herausgegeben von Christian STARCK, Erster band (primer volumen), J.C.B. Mohr (Paul Siebeck), Tübingen, 1976, pp. 63 y ss.; en concreto, p. 74. El otro peligro que, según Zweigert, se cierne sobre un Tribunal Constitucional es el de una autoalienación a través de un déficit de realidad ("eine Selbstentfremdungdurch ein Realitätsdefizit").

140 SILVESTRI, Gaetano (1981). "Le sentenze normative della Corte costituzionale”, en Giurisprudenza Costituzionale, anno XXVI, fasc. 8/10, 1981, pp. 1684 y ss.; en concreto, p. 1719.

141 En pocas, pero acertadas, palabras compendia Rostow la relevancia del principio en cuestión: "The separation of powers under the Constitution serves the end of democracy in society by limiting the roles of the several branches of government and protecting the citizen, and the various parts of the state itself, against encroachments from any source. The root idea of the Constitution is that man can be free because the state is not". V. Rostow, Eugene. (1952). "The democratic character of judicial review", en Harvard Law Review, volume 66, December 1952, pp. 193 y ss.; en concreto, p. 195. 
Birke, en específica alusión al control de las omisiones legislativas, ha podido escribir que "el principio de la división de poderes no puede encontrar aplicación cuando uno de los poderes, esto es, el legislador, no ejercita las funciones que tiene atribuidas. ${ }^{142} \mathrm{~A}$ su vez, Scholz razona que los límites sobre el control constitucional y la función política no siempre son unívocos y que también el poder legislativo, ocasionalmente, ha asignado al BVerfG, al menos fácticamente, el papel de "legislador sustituto" por obra de sus propias falencias u omisiones. ${ }^{143}$ En análoga dirección, Schlaich argumenta que el principio de la división de poderes prevé la complementariedad y el apoyo por parte de todas las instituciones respecto de aquellos órganos que no se encuentren en condiciones de concluir completamente sus funciones. ${ }^{144}$ Según este planteamiento funcional, el $B$ VerfG, por ejemplo, podría colmar provisionalmente un vacío legislativo, desarrollando las funciones propias del legislador. En fin, el mismo Bachof se ha referido a cómo los Tribunales Constitucionales, en ocasiones, adoptan una regulación transitoria, por lo que, en cierto modo, actúan como legisladores sustitutos. ${ }^{145}$

Con todo, no obstante las apreciaciones que preceden, creemos que sería erróneo pensar en que cuando el Tribunal Constitucional federal ha podido adoptar decisiones que parecieran convertirlo en legislador sustituto, ello lo ha hecho para suplantar al legislador. Bachof ha efectuado al respecto una precisión de interés, al subrayar que la asunción transitoria por los Tribunales Constitucionales de funciones propias del legislador no la llevan a cabo "para ganarle de mano al legislador, sino precisamente para todo lo contrario, esto es, para salvaguardarle la necesaria libertad de movimiento requerida para una regulación definitiva". ${ }^{146}$

Las reflexiones que anteceden pueden considerarse una obviedad y, en cuanto tal, algo innecesario de mención. Sin embargo, el constitucionalismo comparado nos revela la necesidad de insistir en ciertos aspectos dogmáticos por obvios que puedan parecer, por cuanto no faltan sistemas que contradicen abiertamente tan elementales principios. Podemos recordar al respecto, que al hilo del procedimiento de control de las omisiones legislativas, algunas entidades federativas de México han convertido a sus órganos titulares de la justicia constitucional en verdaderos colegisladores. Tal es el caso del Estado de Veracruz, en el que una reforma constitucional del año 2000 ha habilitado al órgano de fiscalización, el Superior Tribunal de Justicia del Estado, para que, una vez reconocida en sede judicial la omisión legislativa inconstitucional y fijado

\footnotetext{
142 BIRKE (1968). Richterliche Rechtsanwendung und gesellschaftliche Auffassungen, Köln, p. 21. Cit. por TROCKER, Nicolò. "Le omissioni del legislatore e la tutela giurisdizionale...”, op. cit., p. 124, nota 65.

143 Scholz, Rupert (2002). "Alemania: cincuenta años de la Corte Constitucional Federal”, en Anuario de Derecho Constitucional Latinoamericano, Konrad Adenauer Stiftung, edición 2002, pp. 57 y ss.; en concreto, p. 72.

${ }^{144}$ SCHLAICH, Klaus (1982). "Corte costituzionale e controllo sulle norme nella Repubblica Federale di Germania”, en Quaderni Costituzionali, anno II, n 3, Dicembre 1982, pp. 557 y ss.; en concreto, p. 584.

145 BACHOF, Otto (1986). "Nuevas reflexiones sobre la jurisdicción constitucional entre Derecho y política", en Boletín Mexicano de Derecho comparado, año XIX, n 57 , Septiembre/Diciembre 1986, pp. 837 y ss.; en concreto, pp. 848-849.

146 BACHOF, Otto (1986), p. 849.
} 
un plazo de dos períodos de sesiones ordinarias del Congreso del Estado para que éste expida la ley o decreto omisos e incumplida la expedición del texto, dicte las bases a que deben quedar sujetas las autoridades hasta que se expida la ley o decreto omisos. De esta forma, el Tribunal se convierte en legislador. Algo análogo puede decirse del Estado de Chiapas, en el que, tras la reforma constitucional del año 2007, el Tribunal Constitucional del Estado que en ese mismo momento se crea asume similar función legislativa en un supuesto sustancialmente semejante.

Unas previsiones como las que se acaban de mencionar nos parecen por entero inaceptables en cuanto claramente atentatorias contra la libertad de configuración del legislador, el cual, como es bien sabido, en modo alguno se encuentra respecto de la Constitución en la misma situación que el poder reglamentario respecto de la ley. El legislador se halla lejos de ser un mero ejecutor de la Constitución, cuyas cláusulas abiertas le permiten diferentes desarrollos normativos, que a su vez el poder legislativo, que actualiza de modo permanente la voluntad soberana del pueblo, está plenamente legitimado para precisar en una u otra dirección, innecesario es decir que con respeto en todo caso de las cláusulas constitucionales.

A nuestro entender, es un tópico decir que la conversión del juez constitucional en legislador conculca de modo frontal el principio de la división de poderes, una de las claves de bóveda de la arquitectura constitucional, pero conviene añadir que lo grave de tal vulneración no es tan sólo que un poder del Estado asuma la función reservada a otro, sino que se asuma la función legislativa sin quedar sujeto a responsabilidad alguna, pues es patente que el poder legislativo, al inclinarse en su diseño normativo por una de las varias opciones de desarrollo que la Constitución le permite, ejerce una opción política para la que se encuentra específicamente legitimado y a la que, se quiera o no, se anuda una responsabilidad que el cuerpo electoral puede sancionar en el momento en que acuda a las urnas. Como escribiera Simon en alusión a su país, aunque sea una reflexión sin fronteras, la decisión del constituyente alemán en favor de una democracia asentada en la división de poderes veda una interpretación sin límites que, eludiendo la reforma constitucional, difumine los lindes entre interpretación y potestad normativa y haga subrepticiamente soberano a quien únicamente es custodio de la Constitución. ${ }^{147}$ Y esta reflexión, que compartimos por entero, creemos que puede proyectarse válidamente sobre el problema que nos ocupa.

No es ajeno a las reflexiones anteriores que las Constituciones portuguesa y brasileña hayan privado al juez constitucional de toda posibilidad de suplir la omisión del legislador cuando, conociendo del instituto de control de la misma, lleguen a la conclusión de que la inacción es contraria a la Constitución. Más aún, ni tan siquiera han previsto la posibilidad de que el juez constitucional, declarada la inconstitucionalidad de la omisión legislativa, pueda fijar compulsivamente un plazo al legislador a fin de que éste, dentro del mismo, proceda a dictar la ley omisa.

147 Simon, Helmut (1996). "La Jurisdicción Constitucional”, en Benda, Malhofer, Vogel, Hesse y Heyde, Manual de Derecho Constitucional, (Madrid, IVAP/Marcial Pons), pp. 823 y ss.; en concreto, p. 854. 
Cuestión por entero distinta de la anterior, y en la que no vamos a entrar, es la atinente a la valoración de la mayor o menor funcionalidad de los efectos de la declaración de inconstitucionalidad de una omisión absoluta, constatada a través de un control abstracto. Los efectos son, qué duda cabe, bastante limitados, pero ello no quiere decir que no se pueda extraer de tales declaraciones alguna consecuencia de interés. La más relevante, a nuestro juicio, es la de publicitar la inconstitucionalidad en que ha incurrido el legislador, que en ciertos contextos puede tener una significativa trascendencia. De hecho, podrá actuar de antídoto, de eficacia limitada si se quiere, frente a los legisladores de aquellos países con una reconocida tradición de sistemático incumplimiento de las normas constitucionales, como podría ejemplificar paradigmáticamente el legislador brasileño, por lo menos el que antecede a la Constitución de 1988, lo que da pleno sentido a la pluralidad de instituciones procesales, de control de la constitucionalidad de la omisión y de tutela de los derechos frente a su vulneración resultante de una inacción legislativa, que el constituyente brasileño consagró hace una veintena de años.

\section{BIBLIOGRAFÍA}

AdAm, Antal (2000): “La Cour constitutionnelle en Hongrie”, en Giustizia costituzionale e sviluppo democratico nei paesi dell'Europa centro-orientale, a cura di de VERGoTtıNI, Giuseppe, (Torino, G. Giappichelli Editore), pp. 207 y ss.

Alves Correia Fernando (2001: Direito Constitucional. A Justiça Constitucional, (Coimbra, Almedina),

Aмато, Giuliano (1971): “Troppo coraggio o troppa cautela nella Corte contestata?", en Giurisprudenza Costituzionale, anno XVI, fasc. 2, pp. 603 y ss.

Anzon, Adele (1992): "Nuove tecniche decisorie della Corte costituzionale", en Giurisprudenza Costituzionale, ann XXXVII, fasc. 4, Luglio/Agosto 1992, pp. 3199 y ss.

BACHOF, Otto (1986): "Nuevas reflexiones sobre la jurisdicción constitucional entre Derecho y política”, en Boletín Mexicano de Derecho Comparado, año XIX, $n^{\circ} 57$, Septiembre/Diciembre 1986, pp. 837 y ss.

Barbosa Moreira, José Carlos (2003): "El control judicial de la constitucionalidad de la leyes en el Derecho brasileño: un bosquejo”, en Eduardo Ferrer Mac-Gregor (Coord.), Derecho Procesa Constitucional, 4 a ed., Editorial Porrúa/Colegio de Secretarios de la Suprema Corte de Justicia de la Nación, México, tomo III, pp. 1991 y ss.

BÉGuIN, Jean-Claude (1982): Le contrôle de la constitutionnalité des lois en République Fédërale d'Allemagne (Paris, Economica).

BöCKENFÖRDE, Ernst-Wolfgang (1993): Escritos sobre Derechos Fundamentales (BadenBaden, Nomos Verlagsgesellschaft).

Bonavides, Paulo y Paes de Andrade (1991): História Constitucional do Brasil, $3^{\text {a }}$ ed., Editora Paz e Terra, Rio de Janeiro.

Cappelletti, Mauro (1955): La giurisdizione costituzionale delle libertà (Primo studio sul ricorso costituzionale), (Milano, Giuffrè Editore).

CAppelletti, Mauro (1990): "Des juges législateurs?" (Étude dédiée à la mémoire de Tullio Ascarelli et d'Alessandro Pekelis). Recogido en la obra recopilatoria de artícu- 
los del autor, Le pouvoir des juges, (Paris, Economica/Presses Universitaires d'AixMarseille), pp. 23 y ss.

Cappelletti, Mauro (1971): Judicial Review in the Contemporary World, (Indianapolis/ Kansas, The Bobbs Merrill Company).

Cervati, Angelo Antonio (1989): "Incostituzionalità delle leggi ed efficacia delle sentenze delle Corti costituzionali austriaca, tedesca ed italiana”, en Quaderni Costituzionali, anno IX, n 2, Agosto 1989, pp. 257 y ss.

Corwin, Edward S. (1963): The "Higher Law». Background of American Constitutional Law, Great Seal Books, fifth printing, (Ithaca, New York, A Division of Cornell University Press).

Crisafull, Vezio (1967): "Le sentenze «interpretative» della Corte costituzionale", en Rivista trimestrale di Diritto procedura civile, anno XXI, n ${ }^{\circ}$, Marzo 1967, pp. 1 y ss.

Crisafull, Vezio (1977): "Giustizia costituzionale e potere legislativo", en Aspetti e tendenze del Diritto costituzionale. Scritti in onore di Costantino Mortati, Giuffrè, Milano, vol. $4^{\circ}$, pp. 129 y ss.

CrISAfull, Vezio (1984): Lezioni di Diritto costituzionale, vol. II (L'ordinamento costituzionale italiano. Le fonti normative. La Corte costituzionale), $5^{\mathrm{a}}$ edizione riveduta (Padova, CEDAM).

CrISAfulli, Vezio (1984): "La Corte costituzionale ha vent'anni”, en La Corte costituzionale tra norma giuridica e realtà sociale (Bilancio di vent'anni di attività), a cura di Nicola Occhiocupo, CEDAM, Padova, 1984 (ristampa), pp. 69 y ss.

D'Orazio, Giustino (1972): "Le sentenze costituzionali additive tra esaltazione e contestazione", en Rivista trimestrale di Diritto pubblico, fasc. 1, pp. 61 y ss.

Da Cunha Ferraz, Anna Cândida (2005): "Protecçâo jurisdicional da omissâo inconstitucional dos poderes locais”, em Revista Mestrado em Direito, ano 5, n 5 (Sâo Paulo, Osasco).

Delfino, Felice (1974): “Omissioni legislative e Corte costituzionale (delle sentenze costituzionali c. d. creative)", en Studi in onore di Giuseppe Chiarelli, Giuffrè, Milano, tomo secondo, pp. 911 y ss.

ELIA, Leopoldo (1965): "Divergenze e convergenze della Corte costituzionale con la magistratura ordinaria in materia di garanzie difensive nell'istruzione sommaria”, en Rivista italiana di Diritto e procedura penale, nuova serie, anno VIII, 1965, pp. 537 y ss.

FERNÁNDEZ SEGADO, Francisco (2008): "El control de las omisiones legislativas por el "Bundesverfassungsgericht”", en Teoría y Realidad Constitucional, $\mathrm{n}^{\circ} \mathrm{22}, \mathrm{2}^{\circ}$ semestre 2008, pp. 95 y ss.

FernÁNdez Segado, Francisco (2009): La justicia constitucional: una visión de Derecho comparado, tomo I, (Madrid, Dykinson).

Ferreira Mendes, Gilmar (1992): "O apelo ao legislador (Appellentscheidung) na práxis da Corte Constitucional Federal alemana”, en Revista da Faculdade de Direito da Universidade de Lisboa, vol. XXXIII, 1992, pp. 265 y ss.

Ferreira Mendes, Gilmar (2007): "O controle da omissâo inconstitucional”, en Jairo Gilberto Schäfer (organizador), Temas polêmicos do constitucionalismo contemporâneo (Florianópolis, Conceito Editorial).

Gomes Canotilho, J.J (2002): Direito Constitucional e Teoría da Constituiçâo, $5^{a}$ ediçâo, (Coimbra, Almedina). 
Gomes Canotilho, J.J. y Moreira, Vital (1978): Constituiçâo da República Portuguesa. Anotada, (Coimbra; Coimbra Editora).

Gomes Canotilho, J.J. (1982): Constituiçâo dirigente e vinculaçâo do legislador (Contributo para a compreensâo das normas constitucionais programáticas), (Coimbra, Coimbra Editora).

Guerra Filho, Willis Santiago (2001): Processo Constitucional e Direitos Fundamentais, $2^{a}$ ediçâo, (Sâo Paulo, revista Celso Bastos editor).

Kelsen, Hans (1949): Teoría General del Derecho y del Estado, (México Imprenta Universitaria).

LANDFRIED, Christine (1988): "Constitutional Review and Legislation in the Federal Republic of Germany", en Landfried, Christine (Ed.), Constitutional Review and Legislation. An International Comparison, Nomos Verlagsgesellschaft, Baden-Baden, 1988, pp. 147 y ss.

LeiBHOLz, Gerhard (1957): "Einleitung”, en "Der Status des Bundesverfassungsgerichts" (Gutachten, Denkschriften und Stellungnahmen mit einer Einleitung), en Jahrbuch des Öffentlichen Rechts der Gegenwart, band 6, pp. 110 y ss.

Medeiros, Rui (1999): A Decisâo de Inconstitucionalidade (Os autores, o conteúdo e os efeitos da decisâo de inconstitucionalidade da lei) (Lisboa, Universidade Católica Editora).

MichelmanN, Frank I (1979): "Welfare Rights in a Constitutional Democracy", en Washington University Law Quarterly, volume 1979, number 3, Summer 1979, pp. 659 y ss.

Miranda, Jorge (1977): "Inconstitucionalidade por omissâo", en la obra coloectiva, Estudos sobre a Constituiçâo, vol. I, Livraria Petrony, Lisboa, 1977, pp. 333 y ss.

Miranda, Jorge (2001): Manual de Direito Constitucional, tomo VI (Inconstitucionalidade e Garantía da Constituiçâo), (Coimbra, Coimbra Editora).

Miranda, Jorge (2003): "O Tribunal Constitucional Português em 2002”, en Anuario Iberoamericano de Justicia Constitucional, $\mathrm{n}^{\circ} 7,2003$, pp. 561 y ss.

Modugno, Franco (1985): "La Corte costituzionale oggi”, en Scritti su la Giustizia Costituzionale. In onore di Vezio Crisafulli, (Padova, CEDAM), 1985, vol. I, pp. 527 y ss.

MorTATI, Costantino (1972): “Appunti per uno studio sui rimedi giurisdizionali contro comportamenti omissivi del legislatore”, en la obra del propio autor, Problemi di Diritto pubblico nell' attuale esperienza costituzional repubblicana (Raccolta di ScrittiIII), Giuffrè, Milano, pp. 923 y ss.; en concreto, p. 992. Artículo inicialmente publicado en II Foro Italiano, 1970, V, pp. 153 y ss.

Othon Sidou, J. M. (2002): "Habeas Corpus”, Mandado de Segurança, Mandado de Injunçâo, "Habeas Data”, Açâo Popular, $\sigma^{a}$ ediçâo, Editora Forense, Río de Janeiro.

PalAdin, Livio (1956): "Osservazioni sulla discrezionalità e sull'eccesso di potere del legislatore ordinario", en Rivista Trimestrale di Diritto Pubblico, anno VI, 1956, pp. 993 y ss.

Paladin, Livio (1991): Diritto costituzionale, (Padova, CEDAM).

Pereira Da Silva, Jorge (2003): Dever de legislar e protecçâo jurisdicional contra omissôes legislativas (Contributo para uma Teoria da Inconstitucionalidade por Omissâo), (Lisboa, Universidade Católica Editora).

Pestalozza, Christian (1991): Verfassungsprozessrecht (Die Verfassungsgerichtsbarkeit des Bundesund der Länder), C.H. Beck'sche Verlagsbuchhandlung, 3, völlig neubearbeitete Auflage ( $3^{a}$ ed. completamente revisada), München. 
PICARDI, Nicola (1977): “Le sentenze «integrative» della Corte costituzionale”, en la obra colectiva, Aspetti e tendenze del Diritto costituzionale. Scritti in onore di Costantino Mortati, Giuffrè Editore, Milano, vol. $4^{\circ}$, pp. 597 y ss.

Pizzorusso, Alessandro (1984): "El Tribunal Constitucional italiano”, en la obra colectiva, Tribunales Constitucionales Europeos y Derechos Fundamentales, (Madrid, Centro de Estudios Constitucionales).

RIBES, Didier. "Le juge constitutionnel peut-il se faire législateur? (À propos de la décision de la Cour Constitutionnelle d'Afrique du Sud du 2 décembre 1999)", en Les Cahiers du Conseil constitutionnel, $\mathrm{n}^{\circ}$ 9, Mars 2000/ Septembre 2000.

RoussiLlon, Henry (1977): "Le problème du contrôle de la constitutionnalité des lois dans les pays socialistes”, en Revue du Droit Public, n 1-1977, Janvier/Février 1977, pp. 55 y ss.

Rupp-V. BRüNNECK, Wiltraut (1970): "Darf das Bundesverfassungsgericht an den Gesetzgeber Appellieren?”, en Festschrift für Gebhard Müller (Zum 70. Geburtstag des Präsidenten des Bundesverfassungsgerichts), Herausgegeben von Theo RitTERSPACH und Willi GeIGer, J.C.B. Mohr (Paul Siebeck), Tübingen, pp. 355 y ss.

SAndulli, Aldo M. (1962): "Die Verfassungsgerichtsbarkeit in Italien”, en Verfassungsgerichtsbarkeit in der Gegenwart (Länderberichte und Rechtsvergleichung) (Köln/Berlin, Herausgegeben von Hermann Mosler, Carl Heymanns Verlag KG), pp. 292 y ss.

SAndulli, Aldo M. (1967): Il giudizio sulle leggi (La cognizione della Corte costituzionale e i suoi limiti) (Milano, Giuffrè).

Schlaich, Klaus (1982): "Corte costituzionale e controllo sulle norme nella Repubblica Federale di Germania”, en Quaderni Costituzionali, anno II, ${ }^{\circ}$ 3, Dicembre 1982 , pp. 557 y ss.

SCHNEIDER, Hans-Peter (1982): “Jurisdicción constitucional y separación de poderes", en Revista Española de Derecho Constitucional, $\mathrm{n}^{\circ} 5$, mayo/agosto, pp. 35 y ss.

ScHOLz, Rupert (2002): “Alemania: cincuenta años de la Corte Constitucional Federal”, en Anuario de Derecho Constitucional Latinoamericano, Konrad Adenauer Stiftung, edición 2002, pp. 57 y ss.

Schulte, Martin (1988): “Appellentscheidungen des Bundesverfassungsgerichts", en Deutsches Verwaltungs Blatt (DVBI), 103. Jahrgang, 15 Dezember 1988, pp. 1200 y ss.

SILVESTRI, Gaetano (1981): "Le sentenze normative della Corte costituzionale", en Giurisprudenza Costituzionale, anno XXVI, fasc. 8/10, 1981, pp. 1684 y ss.

Simon, Helmut (1996): “La Jurisdicción Constitucional”, en Benda, Maihofer Vogel, Hesse y Heyde, Manual de Derecho Constitucional, (Madrid, IVAP/Marcial Pons).

Siqueira Castro, Carlos Roberto (2006): O devido processo legal e os princípios da razoabilidade e da proporcionalidade, $4^{a}$ ed., (Río de Janeiro, Editora Forense).

SORRENTINO, Federico (1985): "Strumenti tecnici e indirizzi politici nella giurisprudenza della Corte costituzionale”, en Scritti su la Giustizia Costituzionale. In onore di Vezio Crisafulli, (Padova, CEDAM), tomo I, pp. 795 y ss.

STRECK, Lenio Luiz (2004): Jurisdiçâo Constitucional e Hermenêutica (Uma Nova Crítica do Direito), $2^{\text {a }}$ ediçâo, (Río de Janeiro, Revista, Editora Forense).

TROCKER, Nicolò (1970): "Le omissioni del legislatore e la tutela giurisdizionale dei diritti di libertà (Studio comparativo sul diritto tedesco), en Archivio Giuridico "Filippo Serafini”, volume CLXXVIII, Fascicoli 1-2, Gennaio/Aprile, 1970, pp. 88 y ss. 
VIeIRA de Andrade, José Carlos (2007): Os Direitos Fundamentais na Constituiçâo Portuguesa de $1976,3^{a}$ ediçâo, $2^{a}$ reimpressâo, (Coimbra, Almedina).

Villaverde Menéndez, Ignacio (1997): La inconstitucionalidad por omisión, (Madrid, McGraw-Hill).

Von BRüNneCK, Alexander (1988): "Constitutional Review and Legislation in Western Democracies", en Landfried, Christine (Ed.), Constitutional Review and Legislation. An International Comparison, (Baden-Baden, Nomos, Verlagsgesellschaft), pp. 219 y ss.

Wessel (1952): "Die Rechtsprechung des Bundesverfassungsgerichts zur Verfassungsbeschwerde”, en Deutsches Verwaltungsblatt (DVBI), 67. Jahrgang, Heft 6, 15. März, pp. 161 y ss.

ZaGReBelSKY, Gustavo (1977): La giustizia costituzionale (Bologna, Il Mulino).

ZaKRZEWSKA, J. (1972): "Le contrôle de la constitutionnalité des lois dans les États socialistes”, en Res Publica (Revue de l'Institut Belge de Science Politique), vol. XIV, $1972, \mathrm{n}^{\circ} 4$, pp. 771 y ss.

ZEIDLER, Wolfgang (1987): "Cour constitutionnelle allemande" (7ème Conférence des Cours constitutionnelles européennes), en Annuaire International de Justice Constitutionnelle, III, 1987, pp. 37 y ss.

ZWEIGERT, Konrad (1976): "Einige rechtsvergleichende und kritische Bemerkungen zur Verfassungsgerichtsbarkeit”, en Bundesverfassungsgericht und Grundgesetz (Festgabe aus Anlass des 25 jährigen Bestehens des Bundesverfassungsgerichts), herausgegeben von Christian StARCK, Erster band (primer volumen), J.C.B. Mohr (Paul Siebeck), Tübingen, 1976, pp. 63 y ss. 